\title{
MNIVIVRSITY OF \\ CAMBRIDGE
}

\section{Cambridge Working Papers in Economics}

\section{Religious Riots and Electoral Politics in India}

Sriya Iyer, Anand Shrivastava

21 November 2015 


\title{
Religious Riots and Electoral Politics in India*
}

\author{
November 21, 2015
}

\section{Sriya Iyer ${ }^{1} \quad$ Anand Shrivastava ${ }^{2}$}

\begin{abstract}
The effect of ethnic violence on electoral results provides useful insights into voter behaviour in democratic societies. Religious riots have claimed more than 14,000 lives in India since 1950. We study the effect of Hindu-Muslim riots on election results in India. We combine data on riots, which have been geo-coded, with electoral data on state legislature elections and control variables on demographics and public goods provision to construct a unique panel data set for 16 large states in India over a 21 year period from 1981-2001. We suggest a new instrument that draws upon the random variation in the day of the week that important Hindu festivals fall on in each year, as set by a lunar calendar. The probability of a riot increases if a Hindu festival falls on a Friday, the holy day for Muslims. This allows us to isolate the causal effect of riots on electoral results. We also correct for under-reporting of riots and how they affect electoral outcomes in nearby districts. We find that riots occurring in the year preceding an election increases the vote share of the Bharatiya Janata Party by 5 to 7 percentage points in the election.
\end{abstract}

\section{JEL codes: Z12, D72, D74}

*This work has been funded by the Spiritual Capital Research Program, sponsored by the Metanexus Institute on Religion and Science, with the generous support of the John Templeton Foundation. We would also like to acknowledge funding support from the Gates Cambridge Trust, the Centre for Research in Microeconomics and the Faculty of Economics, Cambridge. We would like to thank Steven Wilkinson for generously sharing his data on religious riots from 1950-1995 in India. We are grateful to Rachana Shanbhogue, Paul Sweeny and Shreya Nanda for excellent research assistance. For their help, comments and suggestions, we are grateful to Toke Aidt, Jean-Marie Baland, Eli Berman, Guilhem Cassan, Partha Dasgupta, Sanjeev Goyal, Timothy Guinnane, Gabriel Leon, Hamish Low, Chander Velu, seminar and conference participants at the University of Namur, Paris School of Economics, PODER summer school, ASREC 2015 Boston, and Yale University.

${ }^{1}$ Corresponding author: Faculty of Economics and St. Catharine's College, University of Cambridge. Austin Robinson Building, Sidgwick Avenue, Cambridge CB3 9DD, United Kingdom. Tel: 441223 335257; Fax: 441223 335475; si105@cam.ac.uk.

${ }^{2}$ Faculty of Economics and Queens' College, University of Cambridge. as2073@cam.ac.uk 


\section{Introduction}

How do voters choose to cast their vote? This question fascinates economists and has many answers (Ansolabehere, 2008). In models of rational choice voters maximise their expected utilities under different candidates or parties and choose their votes accordingly (Downs, 1957). In keeping with these models, the factors influencing voting behaviour include the allocation of public goods and public services, bureaucratic efficiency and macroeconomic policies (Kramer, 1971; Stigler, 1973; Fair, 1996). Broadening this model of voter behaviour, we can include identity in the individual voter's preferences, thus making the ethnic, religious or racial identity of the candidate or the party an important factor in elections (Glaeser, 2005; Fearon, 1999). Identity politics and conflict based on ethnic identity is widespread across the world. Our contribution is to assess the impact of ethno-religious riots on the results of democratic elections. Investigating this question provides insights into the direction and magnitude of the effect of ethno-religious polarisation, or increased salience of ethno-religious identity, on voters' decisions.

Our work is in keeping with an emerging literature that uses economic and statistical methods to evaluate the role of religion in society (see Iyer, 2016 for an overview). As well, a much broader literature has been examining the effect of ethnic, social and armed conflict on economic, demographic, developmental and political outcomes (Beck and Tolnay, 1990; DiPasquale and Glaeser, 1998; Posner, 2004; Berrebi and Klor, 2008; Eifert, Miguel and Posner, 2010; Berman, Dinecco and Onoraro, 2015; Downey and Felter, 2015; Michalopoulos and Papaioannou, 2015; Skaperdas, 2015). Some of this research examines issues as diverse as ethnicity and geography, race riots, gang violence, mobs and lynching, terror incidents, warfare, and counter-insurgency programmes. Our work on religious riots and electoral politics in India is in keeping with this much broader concern of the different effects of historical conflict, social violence and inter-group unrest on contemporary economic welfare and political economy. 
Hindu-Muslim riots in India have been the subject of a number of studies, most of which have examined what causes the riots. These causes are social (Brass, 1997, 2003; Varshney, 2002), economic (Bohlken and Sergenti, 2010; Mitra and Ray, 2014, Field et al, 2008) and political (Wilkinson, 2004; Jha, 2014; Pathania and Tandon, 2011; Blakeslee, 2013; Nellis, Weaver and Rosenzweig, 2015). There are very few studies in the economics of India which examine the political implications of the occurrence of riots.

We investigate the effect of Hindu-Muslim riots on state government elections in 16 Indian states from 1981 to 2001 . The riots data is obtained from a data set constructed first by Varshney and Wilkinson (2004) and extended by us, using individual news reports on Hindu-Muslim riots from The Times of India (Mumbai) newspaper. This event-study data is supplemented with electoral data from publicly available information on state assembly elections. The delimitation document (Election Commission, 1976) is used to map electoral constituencies onto administrative districts. The riots and electoral data combined with data on demographics and public goods provision from decennial Indian Censuses are used to construct our unique dataset.

We examine the effect of riots occurring in a district in the year preceding an election on the vote share obtained by the Hindu nationalist Bharatiya Janata Party (BJP) in the election. We find that the effect is positive and significant and remains robust to using different control variables and using fixed effects specifications to account for districtspecific unobservables. We establish the causal effect of riots on electoral results by using a unique instrument for riots. Our instrument is a binary variable that takes the value 1 when an important Hindu festival in a state in a given year falls on a Friday, which is the holy day for Muslims. Anecdotal evidence suggests that religious riots are exacerbated by festivals which are salient for particular religious groups, mainly because these festivals are often associated with very visible public displays of religious faith such as religious processions and collective worship. They are also associated with contestations over public spaces. We hypothesize that such occurrences, whose dates 
are based completely on lunar cycles, increase the probability of riots occurring and find that the data supports this hypothesis. Using this variable to instrument for riots we find a positive and significant causal effect of riots on the vote share of the BJP.

We also analyse the impact of possible under-reporting of riots on both our OLS and IV estimates. We obtain a measure of under-reporting by comparing our dataset to other sources and use the derived expressions for the biases to correct our estimates. We also find that riots affect election outcomes in adjoining districts and that the effect decays with distance. After correcting for under-reporting and distance, we find that a riot in the year preceding an election can lead to an increase in the BJP's vote share by 5 - 7 percentage points.

Establishing exogenous causes for riots has been a major methodological challenge for similar studies. The major contribution of our paper is that it overcomes this challenge by using a unique religious festival instrument and demonstrates the magnitude and direction of the effect of riots on electoral results. The most important implication of our work is that it provides a basis for the argument that the majority identity party has a clear incentive to incite ethnic tensions or even to cause riots. Recent events in India have shown that this was used as a strategy in western Uttar Pradesh (Muralidharan 2014; Rao et al 2014).

Section 2 provides a brief historical background of inter-communal relations and electoral politics in India and reviews the literature on identity politics and ethnic violence, both in India and more widely. Section 3 contains a description of the data used. Section 4 explains the econometric specification and describes the instrument used to identify the causal effect of religious riots on election results. Section 5 describes the regressions and their results. Section 6 concludes. 


\section{Religious Riots and Indian Electoral Politics ${ }^{3}$}

The history of religious riots and politics in India can be divided into 4 phases: preIndependence, between 1947-1980, between 1981-2001, and from 2001 to the present.

In India, there is evidence of religion-related incidents of violence as early as 1714 with a number of riots being reported in the eighteenth and nineteenth centuries. ${ }^{4}$ However, communal incidents were not a regular aspect of provincial life in the nineteenth century (Indian Statutory Commission Report, 1930: 97-107). In the early twentieth century, there were localised riots in eastern and northern India. ${ }^{5}$ In southern and western India, there were no significant riots until 1928 when they affected Bangalore, Nasik, Surat and Hyderabad. There were major riots in Calcutta and Bombay in 1926 and 1928 (see Iyer, 2002 for a more detailed discussion).

As the movement against colonial rule led by the Indian National Congress gathered momentum, domestic politics began to be more communalised. The Muslim League which claimed to represent the Muslims of the country, expressed mistrust in the secular rhetoric of the Congress, claiming that it represented the interests of Hindus only. The Civil Disobedience movement of 1942 yielded fresh outbursts of communal violence, which have been attributed by some historians to imperial forces that tried to control the struggle for independence (Sarkar, 1981). With the end of British rule imminent, the Muslim League's demand for the partition of India along religious lines became the flash point. Serious communal clashes took place, at times repeatedly, in Ahmedabad, Calcutta, Noakhali, Bhagalpur, Dacca, Patna, Bombay and Allahabad in 1946-47. The riots leading up to and continuing through the eventual partition of India and the creation

\footnotetext{
${ }^{3}$ Our account here of the political history of post-Independent India draws heavily on the work of Guha (2007). The history of religious riots is drawn from Iyer (2002).

${ }^{4}$ In the eighteenth century, there were communal riots in Ahmedabad in 1714; in Kashmir in 171920, in Delhi in 1729 and in Vidarbha in 1786. For the nineteenth century, historians report evidence of incidents in Benaras (1809-15), Koil (1820), Moradabad and Kashipur (1833), Bareilly, Kanpur and Allahabad (1837-52) (Bayly 1983).

${ }^{5}$ East Bengal (1907), Peshawar (1910), Ayodhya (1912), Agra (1913), Shahabad (1917) and Katarpur (1918). Between 1920 and 1924 there were riots in Malegaon, Multan, Lahore, Saharanpur, Amritsar, Allahabad, Calcutta, Delhi, Gulbarga, Kohat, Lucknow and Nagpur.
} 
of Pakistan remain the most devastating episode of communal violence in modern India with estimates of the death toll ranging from 200,000 to 1 million people (Pandey, 2001).

After gaining independence in 1947 , India formally became a democratic republic and adopted a written constitution in 1950, with the first general elections being held in 1951. Although the Indian National Congress (INC), the party credited with fighting for independence and then establishing a functioning democracy in India, had had uninterrupted control of the central government under Prime Minister Jawaharlal Nehru, its control was by no means unchallenged. Among the many parties opposing the Congress was the Bharatiya Jana Sangh (BJS), a Hindu nationalist party formed in 1951 by Shyama Prasad Mukherjee, who resigned from Nehru's cabinet, in consultation with the Rashtriya Swayamsevak Sangh (RSS), a Hindu nationalist social organisation. Although there were other smaller Hindu nationalist parties such as the Hindu Mahasabha and the Rama Rajya Parishad, the BJS was the main representative of the Hindu nationalist view. Its vote share grew from $3 \%$ in the first national elections in 1951 to $14 \%$ in the fifth national elections in 1971.

Post-independent India from 1947 to 1949 is not part of our dataset although riots in the aftermath of partition continued during this period. In fact 1950, the first year in our dataset, has the highest number of reported riots, 50, till the 1980s. The period from 1950-1976 was relatively calmer with an average of about 16 riots reported per year. The period that we are concerned with in this paper, 1981-2001, witnessed a much higher rate of incidents of about 47 riots reported per year from across the country. The political events that accompanied this increase in violence are described below.

The 1970s saw division in the ranks of the INC and the Prime Minister Indira Gandhi adopting increasingly populist rhetoric to counter it. Democracy was suspended by Indira Gandhi with the imposition of Emergency in 1975. Leaders of opposition parties including BJS were arrested and the press was censored. The Emergency was lifted in 1977 and elections were conducted at the centre as well as in several states. The Janata 
Party, an agglomeration of parties ranging from the left-leaning Socialist Party to the Hindu nationalist BJS, came to power to form the first non-Congress government at the centre since independence. The government was short lived and collapsed in 1980. The next round of elections saw the resurgence of the INC under Indira Gandhi at the centre as well as in several states. The leaders of the erstwhile BJS left the Janata party to regroup and formed the Bharatiya Janata Party (BJP) in 1980.

The INC retained control of the centre first under Indira and later under her son Rajiv Gandhi, till 1989. The assassination of Indira Gandhi by her Sikh bodyguards in 1984 was followed by a spate of anti-Sikh riots. During this time, the BJP along with other subsidiary associations of the RSS started a movement to build a temple at the site of the disputed Babri Mosque or Babri Masjid in Ayodhya. The movement helped the BJP gain popular support and it came to power in several states. In the general election of 1989 the BJP gathered $11 \%$ of the votes and was the third largest party in parliament after the INC and the Janata Dal, a centrist remnant of the erstwhile Janata Party. It supported a government of the National Front, a coalition of the Janata Dal with some regional parties, under Prime Minister V.P. Singh. This government also did not last long, with the BJP withdrawing support primarily because of V.P. Singh's efforts to stop the Babri Masjid agitation being supported by the BJP. In the subsequent elections in 1991, the BJP gathered 20\% of the votes and established itself as the main opposition party to the INC government led by P.V. Narasimha Rao. In December 1992, the Babri Masjid movement led by the BJP culminated in the demolition of the disputed structure by militant Hindu nationalists. A spate of riots erupted in different parts of the country including Mumbai and Surat.

These riots were followed by a period of comparative calm till 2001. During this time a BJP led government came to power for the first time in 1996, albeit only for a period of 13 days. Eventually the BJP led National Democratic Alliance ruled at the centre from 1998 to 2004. In 2002, a series of riots erupted in the state of Gujarat, where BJP leaders were allegedly directly involved. These riots left at least a thousand people 
dead and forced approximately 98,000 people into refugee camps (Jha 2014). This was followed by a period of relative calm until 2013, when riots again broke out in Kishtwar in Jammu and in Muzaffarnagar in Uttar Pradesh. The involvement of political leaders in both these riots has been the subject of many articles (Muralidharan 2014; Rao et al 2014) and the results of the general elections overwhelmingly and in an unprecedented manner favoured the BJP in both these regions. The question of whether this substantial swing towards the BJP was because of the riots or was part of a nation-wide swing that led to the party's victory in the elections, is difficult to answer. This paper answers exactly the same question, but for previous state elections during 1981-2001 and finds that riots did indeed contribute substantially to increasing the BJP's vote share in that period.

\subsection{Riots and politics}

An overview of the literature examining the causes and the relationship between ethnic politics and ethnic violence is found in Fearon (2008). He concludes that the relationship between the two has not been adequately addressed. Ethno-religious conflicts themselves have been widely researched. Arguably starting with Horowitz (1985), the study of the causes of ethnic conflict has generated a substantial literature. Esteban and Ray (2008) describe how economic polarisation along ethnic lines can lead to ethnic conflict. DiPasquale and Glaeser (1998) focus on the 1960's urban race riots in the USA and find that the individual costs and benefits of rioting, in terms of the probability and size of punishment, unemployment and ownership of property, matter. Hindu-Muslim riots in India have also been well documented: for example, Varshney (2002) describes the role of civic institutions in preventing inter-ethnic violence. Bohlken and Sergenti (2010) find that low economic growth increases the probability of riots occurring, while Mitra and Ray (2014) find that growth in Muslim per-capita expenditures increases the chances of future communal violence while the increase in Hindu per-capita expendi- 
tures has negative or no effect. Field et al (2008) find that rent control restricted the locational choices of workers thus preventing segregation and hence leading to riots in Gujarat. These examples show that the causes of riots are complex, multi-faceted, and may be social, political or economic. The findings on economic and social causes of riots does not preclude the presence of other factors such as electoral politics. However, since communal riots were happening in India before electoral politics existed in the country, this cannot be their sole cause.

The relationship between electoral politics and Hindu-Muslim riots in India has been explored in a few studies. Wilkinson (2004) shows that riots are less likely in states with higher effective number of political parties and where the ruling party depends on minority votes. At the local level, using data from 167 towns in the state of Uttar Pradesh, he finds that higher electoral competition measured as the closeness of state elections in towns leads to the higher likelihood of riots. Varshney and Gubler (2012) present criticisms of both results. They suggest that the role of the state governments might have been overstated with respect to the first result and they raise certain methodological objections about the mapping of electoral constituencies onto towns for the second one. Wilkinson's second result finds support from Jha (2014), whose study focussed on the state of Gujarat finding that close elections do indeed predict a higher likelihood of riots at the level of towns. Jha (2014) also finds significant effects of historical inter-ethnic relationships on the duration of riots.

Apart from electoral competition, another strand of the literature focusses on the relationship between the electoral results of the majority identity party, in this case the Bharatiya Janata Party (BJP) and the incidence of riots. Pathania and Tandon (2011) investigate the relationship between the BJP's results in the 1989 and 1991 national elections and the incidence of riots. They find that the share of close elections won by the BJP is positively correlated with the severity of subsequent riots, as measured by the number of people killed or injured or as the duration of the riot. They do not find any correlation between the results of the BJP and the frequency of riots. They do find 
a correlation between riots and the number of close elections, similar to the electoral competition literature discussed above. Nellis, Weaver and Rosenzweig (2015) find that a victory of the Indian National Congress in close elections for the state assembly between 1962 and 2000 led to a reduction in Hindu-Muslim riots. Blakeslee (2013) shows that the BJP's campaign involving its leaders touring northern India as part of the Babri Masjid agitation led to an increase in the party's vote share in the subsequent national elections in 1991, as well as an increase in the probability of riots.

Although many scholars refer to the relationship between riots and politics, more so in the case of India, there have been few studies of the effect of ethnic violence on electoral politics. Blattman (2009) finds that in northern Uganda, violence led to increased political participation in the form of increased voting and community leadership. Aidt and Franck (2015) show that the so-called Swing riots in England in 1830-31 increased the votes polled by pro-electoral reform politicians. In India, although the causes of riots and the role political competition may play in them have been studied in great detail, there is no evidence regarding the impact of the riots themselves on electoral results. The assessment of this impact is essential to understand the incentives that ethnic identity-based political parties have in planning their electoral strategy.

In the Indian context, Jha (2014) finds a positive correlation between the duration of riots and an increase in BJP's vote share but makes no attempt to establish a causal relationship. The main focus of the paper is the effect of historical inter-ethnic relationships on present day inter-ethnic dynamics reflected in riots and elections. Brass (2003) in his detailed study of riots and politics in Aligarh in Uttar Pradesh describes the complex relationship between politics and ethnic relations. He writes,

"The gist of my argument on the relationship between party politics and riots were stated in one of my earlier works as follows: "there is a continuum from political rivalry leading to communal riots to political rivalry feeding on communal riots." The continuum may, however start at either end, that is, from political rivalry to riots as well as from communal riots to intensi- 
fied political rivalry. However, the sequence in Aligarh has been primarily in the latter direction, that is, communal riots have preceded and have led to intensification of interparty competition. The mechanisms that lead to this intensification arise from the tendencies that follow from riots to foster increased communal solidarity and polarization, which in turn are promoted by political parties and/or individual candidates who stand to benefit from such solidarity and polarization. The resultant communalization and polarization in turn reduce the electoral prospects of parties and candidates who stand for secular political practices, intercommunal cooperation, and class or caste/baradari mobilization rather than communal mobilization."

It is this change in "electoral prospects" that we attempt to elucidate more clearly in this paper.

\section{Data}

India has a quasi-federal system of government where power is shared between the central government and the state governments. The control over law and order, and hence the handling of riots, is within the state government's ambit. As of 2000, India consisted of 25 states. For this analysis we only look at large states with population greater than 10 million as at the 2001 census. There are sixteen such states that account for $96 \%$ of India's population. These states are Andhra Pradesh, Assam, Bihar, Gujarat, Karnataka, Kerala, Madhya Pradesh, Maharashtra, Orissa, Rajasthan, Tamil Nadu, Uttar Pradesh and West Bengal. This includes three states - Jharkhand, Chattisgarh and Uttarakhand - that were created in 2000. We collected data for 21 years from 1981 to 2001. Data for all variables is consolidated at the level of the district. These are administrative divisions and most public data is available at this level. Over time the districts have been divided and merged to create new ones. We use the district as defined in the delimitation order released by the Election Commission of India in 1976 and match the rest of the 
data to that. This gives us a panel dataset of 339 districts over 21 years.

\subsection{Elections}

Electoral data for state elections was collected from statistical reports released by the Election Commission. We have used data from state elections rather than from national elections as there were only six national elections during the 21 year period and it would be difficult to disassociate the effects of the elections with that of random events happening coterminously. If we consider state elections then there were elections in at least one of the sixteen states in 18 of the 21 years in consideration.

India has a five-year electoral cycle. ${ }^{6}$ So, we have at least four and at most five elections for every state except Jammu and Kashmir, and Punjab, which have three, in this twenty-one year period. Only state-wide election results were considered - by-election results were ignored. Each state has a number of electoral constituencies, ranging from 87 for Jammu and Kashmir to 425 for Uttar Pradesh that elect representatives for the state legislative assemblies. These electoral constituencies are grouped into administrative districts each containing on average eleven constituencies. We use the district instead of the electoral constituency as our geographical unit as all the other data is available at district level. It is still a reasonably small unit since we have 339 districts in the 16 states we are considering. We aggregate the election data that is available at the constituency level to the district level using the official delimitation order (Election Commission, 1976). We construct the vote share of a party as a fraction with the numerator being the total votes polled by the party in the district and the denominator being the total number of valid votes cast in all those constituencies in the district in which the party fielded a candidate. The main dependent variable we use is the vote share of the BJP in a district in an election.

We also construct a control variable BJP government, which is a binary variable that

\footnotetext{
${ }^{6}$ Sometimes early elections are called due to various reasons like no party getting a clear majority or the state government being dismissed by the central government)
} 
has a value of 1 when the BJP is part of the state government for a given district in a given year. This is important because which party controls the state government may play an important role in influencing both electoral results and the occurrence of riots.

\subsection{Riots}

Our main explanatory variable is the occurrence of riots. Data for the riots that occurred between 1980 and 2000 in these 16 states was extracted from a larger dataset that extends from 1950-2006. The initial dataset from 1950-1995 was constructed by Varshney-Wilkinson (2004) and it was extended using individual newspaper reports on riots from the Mumbai edition of The Times of India, held in the India Office archives of The British Library. Most of the observations included the names of towns, villages, and in some cases districts. Using this information, each riot happening in one of the 16 states was matched with one of the 339 districts. The data includes the number of riots that occurred in a year, the duration of the riots and the reported cause of the riot.

Since each observation is a newspaper report of a riot, the actual intensity of the riot that is being reported varies. As shown in Table 1, there are riots that go on for many days. In other cases, reports of riots from the same place are reported over several days and are hence coded as separate riots in our data. So, it is acknowledged that there is some ambiguity over the intensity of violence that each reported incident represents. For this reason we choose to focus on the extensive rather than on the intensive margin. We construct the primary variable of concern as a binary variable indicating if at least one riot occurred in a given district in a given year. Of a total of 7119 district-year observations, 499 had at least one riot, so the unconditional probability of having at least one riot in a year in a district is $7 \%$.

We also geo-coded the location of each riot. Mapping this on to the location of each district allowed us not only to assign the district in which the riot occurred but also to measure the distance of any other district to the location of the riot. 
Table I provides further details of our riots data. More than $70 \%$ district-years that had riots had only one riot in that year. Most of the district-years that had riots had them for only 1 day, but the number of observations of more than 5 days is also significant. Figure 1 shows the variation in number of riots over years. Years 1986 and 1990 have exceptionally high number of riots and we show later that our results are robust to dropping these two years.

[Table I here]

[Figure 1 here]

\subsection{Demographics and public goods}

Demographics play an important role in electoral results and may also be a factor in the occurrence of riots. Hence, we use religious demographic composition, urbanisation and literacy as control variables. The district-wise distribution of these across the country was obtained from three Censuses from 1981 to 2001. A number of changes in the organisation of districts have occurred between 1981 and 2001. A number of new districts were created and old districts were re-named. We conducted a mapping of the districts in each Census year compared to those in 1911. The value of these variables in non-Census years was obtained by linearly interpolating between two consecutive Censuses. Hence we obtain an approximate value of the variable in each year in each district. Among these variables, one would expect the Muslim population share to play an important role. The share of Muslims ranged from almost 0 to more than $98 \%$. However, the distribution is highly skewed with the median at $8.7 \%$ and with three-fourths of the districts having less than $14 \%$ of Muslims.

The provision of public goods may be a factor influencing the choice of voters. Their effect on riots is not self-evident but there is some literature linking economic factors to ethnic violence (Bohlken and Sergenti, 2010; Mitra and Ray, 2014) and we use public goods provision to control for these effects. We again use Census data to 
obtain the percentage of households that have access to tap water and the percentage of households that have access to electricity. As before, we interpolate linearly between Census years to obtain values for other years.

\section{Econometric specification and identification strategy}

We estimate the effect of riots on electoral results using this panel dataset. Our specification is as follows. The subscripts have their usual meanings.

BJP vote share $_{i t}=\alpha+\beta$ Riot $_{i t-1}+\gamma_{1}$ BJP $_{\text {government }}$ ov $-1_{1}+\gamma_{2}$ Demographic controls $_{i t}+$ $\gamma_{3}$ Public goods provision $_{i t}+\gamma_{4}$ Time trend $_{t}+\delta_{i}+\varepsilon_{i t}$

Here $\delta_{i}$ represents district fixed effects. Our main explanatory variable is Riot $_{i t-1}$, which indicates the occurrence of at least one riot in the district in the year before the elections. Here we use the calendar year rather than a twelve month period preceding the election. This is because the year of election is largely pre-decided as it follows the electoral cycle, but the month of election is fixed by the Election Commission taking many factors into account, and riots could be one of them. We do use the preceding twelve month period in one of the robustness checks and find that the results are unchanged.

While estimating this specification would give us the correlation between riots and BJP vote share, interpreting it as a causal effect is problematic. It may be the case that riots are caused in expectation of a good result for the BJP. Another possibility could be the presence of time-varying unobservables that affect both electoral results and the likelihood of riots.

In order to establish the causal effect of riots on electoral results we construct an instrument for riots. Anecdotal evidence from the newspaper reports that is used to construct the riots data shows that a number of riots tend to occur when religious processions are taken out on days of religious significance. These processions are both visible and vocal. For Muslims, Fridays are important religiously as special weekly 
prayers are held in mosques on those days. These generally result in a large congregation of people in the area surrounding the mosque. Hence, Hindu festivals falling on Fridays may lead to contestations over public spaces. The Hindus have a number of festivals of differing importance depending on the state and region. The day on which these festivals fall depends on the Hindu lunar calendar. Hence, we contend that a year when, in a given region, an important Hindu festival also falls on a Friday, the chances of a riot happening is higher. Moreover, these riots may happen on the festival day itself or may be the result of communal tensions created on the festival day or in anticipation of it. Hence, in keeping with our logic, we construct an instrument, Festival, as follows: First we select the five most important Hindu festivals for each state. In this we are guided by the public holidays declared and published officially in each state by the state government. Hence, major festivals such as Dussehra and Diwali that are celebrated across the country were used for all states but festivals such as Holi or Ganesh Chaturthi, which are more local, were used for the respective states in which they are predominantly celebrated (for example in this case in Madhya Pradesh and Maharashtra respectively). The festivals chosen for each state is given in Appendix 1. For districts in each state, the instrument was set equal to one for the year in which one of these festivals fell on a Friday, and it was set equal to zero for all other years. Hence, we construct a completely exogenous instrument with variation in both cross-sectional and time dimensions. As we use this instrument in fixed effects regressions, any statespecific endogeneity inherent in the historical importance of a festival in a given state, is eliminated.

On doing an analysis of variance of the instrument variable on variables indexing the district and the year, we find that the two variables explain $56 \%$ of the variation and from that $98 \%$ is explained by the year variable. Hence, the instrument variable has very little cross-sectional variation and precludes us from using year fixed effects in our main specification. However, in the robustness checks section, we use a different specification that introduces cross-sectional variation using geographical distance measures 
and thus allows us to introduce year fixed effects.

A list of variables with summary statistics is provided in Table II.

[Table II here]

The number of observations of the dependent variable, BJP vote share, is only 1345 because we include only election years, and hence this results in a very unbalanced panel data set. The observations for some of the control variables is also lower than the maximum of 7119 because of some missing data in the Censuses.

\section{Results}

\subsection{Basic specification}

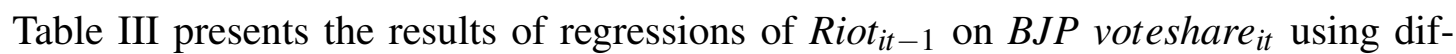
ferent specifications and control variables. As we have panel data we can use fixed effects regression to account for district specific time invariant heterogeneity. We use a quadratic time trend to account for country level variation in the popularity of the BJP. We are not able to use year fixed effects because we have an unbalanced panel and many years with very few observations, hence we lose power on account of using year dummies and lose significance in other estimates as well. In the first column we find that the effect of riots in the previous year on the vote share of the BJP is positive and statistically significant. In the second, third and fourth columns we add controls for demographic variables, namely the percentage of Muslims in the population, urbanisation and literacy; and variables that capture public goods provision, namely the availability of electricity and tap water.

We find that the coefficient of Riot $_{i t-1}$ is consistently positive and significant across all specifications and is robust to the addition of various control variables. The magnitude of approximately 0.03 indicates that a riot is correlated with an increase in the vote share of the BJP by approximately 3 percentage points. The control variables for 
literacy and those for public goods are also significantly correlated with the dependent variable, but it is difficult to interpret these correlations in the absence of exogenous variation in these variables.

[Table III here]

\subsection{Addressing endogeneity}

We have shown that a significant positive correlation exists between the BJP's vote share and riots occurring in the year before elections. To interpret this as a causal effect of riots on vote share, we need to consider a few confounding factors. The first possibility is reverse causation. It may be the case that riots are caused in expectation of a good result by the BJP. Another possibility is the presence of time-varying district specific unobservables that affect both electoral results and the likelihood of riots. To deal with these problems, we use an instrument variable to isolate the exogenous variation in riots.

The instrument we use, as described earlier, is a dummy variable that takes a value 1 whenever an important Hindu festival in a district in a given year falls on a Friday, which is a holy day for Muslims. We hypothesize that such occurrences will lead to increased probability of riots. The first stage regressions shown in Table IV support this hypothesis. The coefficient of the instrument Festival $_{i t-1}$ is positive and highly significant and with an F-statistic much above the cut-off norm of 10. The magnitude of the coefficient indicates that when an important Hindu festival falls on a Friday, this increases the probability of riots by 3 percentage points, which is quite significant as the unconditional probability of a riot occurring is 7 percent.

[Table IV here]

Hence, this instrument satisfies the first requirement of being relevant, i.e. it is correlated with the endogenous variable. The second requirement for the instrument is that it should be exogenous. The dates of Hindu festivals depend on the Hindu lunar calendar and there cannot be any reason to think that the dates on which Hindu festivals fall 
should affect election results other than through riots. Any possible endogeneity introduced by state specific choice of festivals is eliminated in the fixed effects regression.

However, there are two reasons why the exclusion restriction required for the validity of the instrument may be violated. The first reason is that while we have assumed that a riot occurring in a district will influence the election results only in that district, this may not be the case. The area of the electoral effect of the riot may extend beyond the district in which it occurs. If this is the case then the instrument variable, which is common for all districts within the same state, can affect election results in a district not only through riots occurring in that district but through riots occurring in adjoining districts as well. This would violate the exclusion restriction. The second reason could be the under reporting of riots. The instrument could affect the election results through riots which are not reported in the newspaper, thus leading to a bias in the IV coefficient. For the remainder of this subsection, we will ignore these two issues and proceed with using the instrument as if it is valid. In subsequent subsections, we will formulate ways to correct for both of these issues and will present our final set of results.

Table $\mathrm{V}$ shows the results of the reduced form regressions as well as that of the fixed effects 2-stage least squares regressions using Festival $_{i-1}$ as an instrument for Riot $_{i t-1}$. We find that the coefficient of Riot $_{i t-1}$ is positive and significant. The number of observations here is substantially reduced compared to the first stage regression shown above because of the nature of the dependent variable, hence it is essential to check for weak instrument bias. We use the Kleibergen-Paap F-statistic since the standard errors are not i.i.d. but clustered at the level of districts (Kleibergen and Paap, 2006). The StockYogo critical value (Stock and Yogo, 2005) for i.i.d. errors at $10 \%$ maximal IV size is 16.38. In comparison to that the F-statistic is higher in all cases. Hence, we conclude that weak instrument bias is not significant in our case.

[Table $\mathrm{V}$ here]

The IV coefficients shown above should be interpreted as Local Average Treatment 
Effects (LATE). The effect here is the average effect of the increase in probability of riots that occurs because of Hindu festivals falling on Fridays. It may be the case that the effect of riots on vote share is heterogeneous and is particularly high in those places where riots do result from the coincidence of a festival falling on a particular day. Even then, a $20 \%$ vote share gain implies that whenever a riot happens in a year where a Hindu festival falls on a Friday, an election in the next year will almost certainly result in a BJP victory. This seems unrealistic and could be the result of biases discussed earlier viz. larger area of effect of riots and under reporting of riots. We deal with these two issues below.

\subsection{Area of effect of riots}

The reduced form estimates reported in Table V can be crudely interpreted as the difference in average vote share of the BJP between the election years that did and did not have a Hindu festival falling on a Friday in the preceding year. As the mean value of the Festival variable is around 0.53 , this coincidence is fairly common. Hence, a little more than half of the election years would have had this coincidence in the previous year. But the occurrence of a riot in a district is very rare. The exclusion restriction would imply that the increase in the average of the vote shares in a district in all the election years that had the festival coincidence is because of that rare occurrence of a riot that may have happened in one of those years. As mentioned earlier, this may not be the case. The election years in which the festival coincidence did not cause a riot in the same district in the preceding year could have experienced a riot in one of the adjoining districts, and the increased average vote share could be because of these riots as well. Hence, if we account for the riots in adjoining districts, we should be able to overcome this violation of the exclusion restriction.

Since we have the geographical coordinates of the riots, we can construct a variable that is 1 for district $i$ in year $t$, when there is no riot in district $i$ and there is at least one 
riot within a radius of $x \mathrm{~km}$ from the district centre. (The district centre is defined as the location of the largest city in the district.) Introducing this variable in the regression does result in a smaller coefficient of Riot $_{i t-1}$, but it leads to two problems. One is that the occurrence of riots in adjoining districts is very likely endogenous and since it is correlated with the explanatory variable and the instrument, it would be contaminating the coefficient estimate. The second problem is that the choice of the radius of effect $x$ is arbitrary and the coefficient estimates are found to be sensitive to the value chosen. This is to be expected as the effect of riots happening just outside $x$ is assumed to be zero, and any change in the value may just include or just exclude some riots leading to changes in the coefficient.

To overcome these limitations, we construct a new explanatory variable by making the assumption that when there is no riot in district $i$ itself, the election results are influenced by the nearest riot occurring in the preceding year and the effect is lower as the distance of the riot from the district is higher. We define the new variable as $\phi\left(d_{i t-1}\right)$, where $d_{i t-1}$ is the distance of the riot nearest to district $i$ in year $t-1$, and $\phi$ is a decay function such that $\phi(0)=1$ and $\phi(x) \rightarrow 0$ as $x \rightarrow \infty$. The specification now is BJP vote share $_{i t}=\alpha+\beta_{a} \phi\left(d_{i t-1}\right)+\gamma_{1}$ BJP government $_{i t-1}+\gamma_{2}$ Demographic controls $_{i t}+$ $\gamma_{3}$ Public goods provision $_{i t}+\gamma_{4}$ Time trend $_{t}+\delta_{i}+\varepsilon_{i t}$

The coefficient $\beta_{a}$ has the same interpretation as the earlier coefficient. It implies that the vote share of the BJP in state elections in a district will increase by $\beta_{a}$ if at least one riot happened in the same district in the previous year. The first stage regression with the instrument also has a simple interpretation. A Hindu festival falling on a Friday may lead to a riot in the district or in nearby areas and the probability of it leading to a riot decreases as the distance from the district increases.

To estimate this specification, we need to specify the function $\phi$. We choose a Gaussian decay function as it is simple and widely used. The selection of the standard deviation for the distribution still poses a problem. In Table VI we tabulate the results of regressions that include all controls, for a number of values of the standard deviation. 
The average area of a district as of the 1981 Census was around 8000 square kilometres $^{7}$, which corresponds to a circle with radius of approximately $50 \mathrm{kms}$. Hence, we start with a value of $100 \mathrm{kms}$ and increase in steps of $50 \mathrm{kms}$. The coefficient is relatively stable and is approximately in the range of 0.065 to 0.08 for the standard deviation up to the value of $300 \mathrm{kms}$. The value of $200 \mathrm{kms}$ provides the best fit as measured by the smallness of the root mean squared error, Akaike's information criterion as well as the Bayesian information criterion. Hence the corresponding estimate of 0.066 is the best estimate for the coefficient $\beta_{a}$.

[Table VI here]

\subsection{Under-reporting of riots}

As we are using newspaper reports of riots, it is likely that not every riot gets reported. This under-reporting may bias our estimates, as discussed earlier. In order to derive an expression for this bias, we make three assumption regarding the nature of reporting of riots.

1. There is no over reporting, i.e. the newspaper never reports a riot that has not actually happened.

2. Conditional on a district having had one or more actual riots, the probability of at least one riot from that district getting reported is independent of the instrument variable, i.e. riots that are caused because of Hindu festivals falling on a Friday are as likely to be reported as other riots.

3. If a district has had one or more riots in the year before elections, then the effect of those riots on the election results is independent of whether they are reported or not.

\footnotetext{
${ }^{7}$ The surface area of India is 3.288 million square kilometres, which is divided into 412 districts to obtain the average district size.
} 
The third assumption is most likely not true - simply because newspaper reporting of the riots may increase the effect on elections. But making the assumption leads to overestimation of the bias. This implies that the coefficient estimate after correcting for under reporting would be a lower bound for the coefficient.

Let the actual probability of at least one riot occurring in a district be $\lambda$ and given that one or more riots have occurred in the district, the probability of at least one riot being reported be $p$. We show in Appendix 2 that for regressions without other covariates, the OLS and IV estimates, $\hat{\beta}_{O L S}$ and $\hat{\beta}_{I V}$ respectively, calculated using the reported riots would be related to the actual OLS and IV estimates, $\hat{\beta}_{O L S}^{*}$ and $\hat{\beta}_{I V}^{*}$ respectively, as follows.

$$
\begin{gathered}
\hat{\beta}_{O L S}=\frac{1-\lambda}{1-p \lambda} \hat{\beta}_{O L S}^{*} \\
\hat{\beta}_{I V}=\frac{1}{p} \hat{\beta}_{I V}^{*}
\end{gathered}
$$

The bias on the OLS estimate is negative and bounded by $\lambda$, while the bias on the IV estimate is positive and unbounded. We can calculate the bias by getting an estimate of the reporting rate $p$. We use two studies that provide data on all the riots that happened in a particular place in a given time period. We compare these with the riots reported in the newspapers that we used to get an estimate of the reporting rate.

Jha (2014) investigates Hindu-Muslim riots in Gujarat between 27th February and 15th April, 2002. He augments newspaper and online reports with eye witness refugee testimonials and finds a total of 30 riots in this time period. The Times of India, Mumbai edition, that we have used in our dataset, following the methodology adopted by Varshney-Wilkinson, reports only 23. This leads to a reporting rate $p=0.77$. But this is not strictly comparable to our case as all riots happen in a very short span of time and this particular year 2002 is also outside of our sample period 1981-2001. 
A similar exercise using data from Brass (2003) consisting of riots in the city of Aligarh from 1981 until 1995 is more informative. Brass provides information on riots and "riotous periods" using various records including bureaucratic reports and data from NGOs allowing us to check for reporting rates over a long time span. In our dataset Aligarh has had riots in 7 out of the 15 year between 1981 and 1995. Brass provides information about two more riotous years that are not included in our dataset. The resulting reporting rate is $p=0.78$ and is comparable to the one obtained from Jha (2014).

If we use the lower value of $p=0.77$ and apply the under reporting correction to the coefficient estimate obtained in the previous section, we get the value of the estimate as 0.051. As mentioned earlier, this value is a lower bound and the actual coefficient will be between this and 0.066 to the extent that assumption 3 is violated.

\subsubsection{Other concerns with the exclusion restriction}

The validity of the instrument can still be questioned if the occurrence of Hindu festivals falling on a Friday affects vote share directly and not only through riots. It can be argued that the tensions created between Hindus and Muslims due to contestations over public space during such a coincidence could directly lead the Hindus to vote for the BJP. Such tensions at the local level may well change the voting behaviour of the small number of people actually involved in a particular altercation, but will not create any significant impact in the vote share across a district with a population of around a million people. A riot can change voting behaviour through a number of mechanisms, discussed in the next section, through which people who were not directly involved in the rioting change their voting behaviour as they are made more aware of the incident or are indirectly affected by it. An altercation that does not result in any 'incident' cannot affect other people in this way. The other argument could be that the festival coincidence leads to a number of such small unreported altercations across the district that can then lead cumulatively to a change in voting behaviour. If such a phenomenon was so widespread 
then it would be surprising that it has escaped the attention of journalists and academics who scrutinise Indian elections in great detail. On the other hand, the effect of festivals on riots, and that of riots on elections, have been widely reported.

There could be any number of explanations for how the festival coincidence creates something, as Alfred Marshall (1920) wrote albeit in a different context, "in the air", that leads people to change their voting behaviour, but in the absence of a quantifiable measure of such an effect, it is difficult for us to check for or indeed to control for it. We would argue that even if such an effect is present, it is likely to be small and local and may not create a significant bias in our estimates.

\subsection{Mechanisms}

In this section we discuss the different mechanisms through which riots can impact the voting decisions of electors. The arguments in this section are speculative, largely because it is difficult to pin down the exact mechanism of individual behaviour using district level aggregates. Nevertheless we think it is still important to try to interpret some of the trends and correlations that we see in the data. There are three ways in which religious riots could change voting behaviour.

1. Turnout: Riots could leave in their wake an atmosphere of fear and lack of security in public spaces. This could persuade some electors to choose not to go out and vote. It can be argued that voters from the minority religion are going to be more at risk and they are more likely to stay at home for fear of violence. This can result in an increase in the vote share of the party that represents the majority religion, which is the BJP in our case. This is one possible explanation for the results that we have observed in the previous section.

\footnotetext{
${ }^{8}$ Alfred Marshall was interested in manufacturing in Victorian Britain, specifically, why firms in the same industry located geographically close to each other. He argued that proximity created something "in the air" because "... if one man starts a new idea, it is taken up by others and combined with suggestions of their own; and thus it becomes the source of further new ideas." (Marshall, 1920, p.271).
} 
2. Learning: It may be the case that a riot would lead to a change in a person's ideology and/or party affiliation. It is not very clear if this would lead to more or fewer people voting for the party representing the majority religion, but this still can be a feasible explanation for the results that we observe.

3. Salience of religious identity: Religious riots could lead to the religious identity of voters becoming salient causing them to vote for political parties that represent that identity, as suggested by Brass (2003) and many others. In this case, if we assume that a certain fraction of the population of both communities votes according to religion, then the gain for the party representing the majority community would be higher, explaining the increased vote share of the BJP. This effect would be temporary compared to point 2 , which would lead to a more permanent change in voting behaviour.

To check for the presence of the first mechanism, we look for the effect of the nearest riot distance variable $\phi\left(d_{i t-1}\right)$ described in section 5.3, on election turnout. We find that the impact on turnout is negative but not statistically significant. Ideally, we would want to check if the impact is different for Hindus and Muslims, but in the absence of individual-level data we can only conduct an approximate check using the religious composition of the district. If the turnout of Muslims decreases more than that of Hindus, then mechanically the districts with a higher proportion of Muslims should have a larger reduction in turnout after riots. To check for this we conduct a series of regressions over a rolling window of 500 observations in increasing order of the proportion of Muslims in the population. The results are shown in Figure 2. The middle line indicates the point estimate for the coefficient while the two other lines indicate the confidence interval of two times the standard error. We can see that the turnout remains unaffected in districts with more than 5\% Muslim population. In districts with very few Muslims, the turnout may be decreasing because of security threats to a very small minority or because religious polarisation makes the election uncompetitive when one of the reli- 
gions is very small in number. In any case, it is very unlikely that turnout reduction is the reason for the increased BJP vote share as a result of riots.

[Figure 2 here]

To check if riots lead to a permanent change in voting behaviour, we examine the effect of riots at higher lags. We find that the instrument is weak at higher lags as Hindu festivals falling on Fridays do not lead to as much of an increase in riots as they do in the year just preceding the election. ${ }^{9}$ Hence we show the reduced form and the structural estimates at 1,2 and 3 year lags in Figure $3^{10}$. We stop at 3 years because the average gap between elections is 4.4 years. As shown in Figure 2, both the structural and reduced form estimates are not significantly different from zero at higher lags, indicating that riots alter voting behaviour only for the election happening in the immediate year after and not beyond that. This suggests that a possible 'learning' mechanism may not be driving our results.

[Figure 3 here]

By excluding the other two possibilities, the third mechanism seems to be the most likely explanation. There is a large literature in social science which argues that the effect of communal riots on elections is explained primarily by the salience of religious identities (Brass, 2003; Wilkinson, 2004, 2009; Varshney, 2002; Jaffrelot, 2010). Many researchers refer to this phenomenon as 'communal polarisation' or polarisation along religious lines. More precisely, it is the salience of the religious identity of voters as a result of riots that leads voters to vote for the party that best reflects that religious identity. Sen (2006) argues that people have multiple identities which become salient at different times given the environment and context in which they live. In the case

\footnotetext{
${ }^{9}$ If we take this as evidence that political parties or their supporters are using the festival coincidence to instigate riots in the year before elections, then this would suggest that the electoral effect of riots does decay with time, which is why they are being orchestrated in the year before elections.

${ }^{10}$ We include data on riots from years 1978 and 1979 to prevent any observation from being excluded.
} 
of India, some of these identities are religion, caste, language and gender. But the evidence is not limited to India alone. Evidence from Israel suggests that political violence results in increased religiosity among both Jews and Muslims (Zussman, 2014). While religiosity and the salience of religious identity are not exactly the same concept, it is quite likely that they are closely related. Brass (2003) in his extensive study of riots in the city of Aligarh finds that riots lead to the salience of religion as the primary identity, compared to caste. Jaffrelot (2010; pp 381-82) narrates that in the spate of riots in Gujarat in 2002, even Adivasis, the indigenous people thought to be outside the traditional Hindu caste system, joined with the upper castes like the Patidars in assuming a Hindu identity and participating in the riots. There is also evidence of political parties exacerbating and capitalising on this salience of religious identity. As Wilkinson (2009) writes:

"In the Indian state of Gujarat, for instance, a rightwing Hindu politician told an election meeting of Hindus, held in 2002 in the aftermath of riots, that Muslims in the constituency had celebrated with firecrackers and a procession when the news of the murder of Hindu nationalist workers was known. The politician emphasized to voters, 'This is not a Congress versus BJP election. It is Hindus versus Muslims' (Sharma 2004, 1 hour 15 min)."

\subsection{Robustness checks}

\subsubsection{Fractional response}

All the regressions shown above are linear, whereas the dependent variable $B J P$ voteshare $_{i t}$ is a fraction and is thus bounded. To estimate the main regression while allowing for the fractional dependent variable, we use the method suggested by Papke and Wooldridge (2008). The explanatory variable is $\phi\left(d_{i t-1}\right)$, which we name Riot $t_{i t-1}^{\prime}$. This method involves controlling for district level fixed effects by explicitly controlling for the timemeans of the dependent variables. The resulting regression is essentially a random ef- 
fects regression which allows for specifying the estimating equation as a logit or a probit function. The endogeneity correction using the instrumental variable is achieved using the control function approach. The residuals from the first stage regression, also called the control function, are used as additional regressors in the main regression. Papke and Wooldridge suggest two methods for conducting fractional dependent variable regressions controlling for fixed effects and allowing for endogeneity and we conduct both types of regressions. The first is a Bernoulli quasi maximum likelihood estimation and the second is a pooled panel generalised estimating equation approach. In both cases we assume the link function to be probit. We present the results and the estimated average marginal effects in Table VII. Note that we do not use demographic and public goods controls as then the relevant coefficient loses significance in the first stage. Also, we include five year fixed effects ${ }^{11}$ as time fixed effects are recommended in the Papke-Wooldridge procedure - dropping these does not change the results. The marginal effect for the pooled QMLE case is very similar to the linear estimates, while the GEE coefficient estimate is also of the same order but not statistically significant. This demonstrates that a linear approximation may be correct in this case.

[Table VII here]

\subsubsection{Alternative explanatory variable}

Our main explanatory variable is an indicator of at least one riot having taken place in the district in the calendar year before the year in which the election occurred. But elections can take place in different months in a year. So, now we construct the explanatory variable using riots occurring in a 12-month period preceding the election. The results using this variable are shown in Table VIII and they are very similar to our original regressions.

\footnotetext{
${ }^{11}$ We divide the total period of 21 years into four periods of 5-6 years viz, 1981-1985, 1986-1990, 1991-1995, 1996-2001 and we use these dummies as 'five-year fixed effects'. The logic is that within each one of these four periods, we would have elections in all states, thus capturing any country-wide fixed effects.
} 
[Table VIII here]

\subsubsection{Alternative instrument}

In constructing the instrument Festival, we exploited the inter-state differences in the importance of festivals to generate the variation required to obtain a strong instrument. To investigate if our results are robust to changes in the methodology used for constructing the instrument, we construct two alternative instruments. Festival 1 disregards the interstate differences. We select five of the most important Hindu festivals - Dushehra, Diwali, Ramanavami, Janmashtami and Shivaratri and set the instrument as 1 (and 0 otherwise) for all states whenever one of these festivals falls on a Friday. Festival 2 includes only the festivals that vary across states and excludes the two all-India festivals - Dushehra and Diwali. The results are shown in Table IX. The coefficients are positive and significant. The coefficient using Festival 1 is similar to the original regression but the one using Festival 2 is considerably larger.

\section{[Table IX here]}

\subsubsection{Time fixed effects and region specific time trends}

We have not used time fixed effects in our regressions. Here we first show that if we use year fixed effects then we lose power in our regressions. We also use region specific time trends, dividing the states into five regions. ${ }^{12}$ We can see that for the structural regressions shown in columns 1 and 2 of Table X, the coefficient disappears on introducing year fixed effects but is robust to using region specific linear trends. For the IV regressions shown in columns 3 and 4, the point estimates are close to the original value of 0.066 but the standard errors are large. This is probably because the instrument has very little cross-sectional variation.

\footnotetext{
${ }^{12}$ North- Punjab, Haryana and Jammu \& Kashmir, Central- Uttar Pradesh, Rajasthan, Madhya Pradesh and Bihar, East- West Bengal, Assam and Orissa, West- Gujarat and Maharashtra, South- Andhra Pradesh, Karnataka, Tamil Nadu and Kerala.
} 
Time fixed effects are intended to account for unobservable time shocks that affects both the dependent variable and the explanatory variable or the instrument. In our case, the instrument is completely exogenous and so the purpose of time fixed effects would be to check for the possibility that by chance in a few of the election years in which BJP did well, a Hindu festival happened to fall on a Friday in the preceding year and this is driving our result. While we do indirectly check this by dropping some years and states in the next subsection, we cannot directly check for this possibility using time fixed effects because of the lack of cross-sectional variation in the instrument.

We can introduce cross-sectional variation in the instrument by changing our specification slightly. So far we have been looking at the extensive margin of riots to avoid making any assumptions about the nature of the cumulative effect of multiple riots. We now assume a linear cumulative effect, which implies that we can add all the (distance weighted) riots and check for their total effect on elections. The specification would now be

${\text { BJP } \text { vote }_{\text {share }}}_{i t}=\alpha+\beta_{b} \sum_{j=1} \phi\left(d_{i j t-1}\right)+\gamma_{1}$ BJP $_{\mathrm{t})}$ government $_{i t-1}+\gamma_{2}$ Demographic controls $_{i t}+$ $\gamma_{3}$ Public goods provision $_{i t}+\eta_{t}+$ Region specific time trends $s_{i t}+\delta_{i}+\varepsilon_{i t}$

Here, $j$ indicates an individual riot and $n(t)$ indicates the total number of riots in year t. $\phi($.$) is the same Gaussian weighting function that we have used earlier. d_{i j t-1}$ indicates the distance between district $i$ and riot $j$ in year $t-1$. We have replaced the quadratic time trend with individual year fixed effects $\eta_{t}$ and have also included region specific time trends. We call this explanatory variable All riots. We construct a similar expression for the instrument variable for All riots, given by $\sum_{k=1 \text { to } 338} \phi\left(d_{i k}\right)$ Festival $_{k t-1}$. Here, $k$ is a district and $d_{i k}$ denotes the distance between districts $i$ and $k$. Using this instrument implies that a district that is closer to a lot of other districts that are experiencing the coincidence of a Hindu festival falling on a Friday, is likely to have more riots happening near it. This specification allows us to exploit the variation in distances 
between districts that have the coincidence and those that do not, to generate the crosssectional variation necessary for using year fixed effects. The results for the regressions are given in columns 5, 6 and 7 of Table X. The coefficients are positive and significant but have a different interpretation to coefficients of earlier regressions. This coefficient implies that every riot that happens in a district in the year before elections increases the BJP's vote share by 2.1 percentage points. The average number of riots in a district, conditional on having at least one riot is 1.62 . Multiplying this coefficient by 1.62 , we get 3.4 as the average effect of having at least one riot, which is within one standard deviation of the coefficient obtained from our preferred specification in Table VI.

\subsubsection{Dropping states and years}

During the period covered in our study, two of the states that we include - Punjab and Jammu \& Kashmir - underwent a spate of violence between separatist organisations and the state. These separatist movements had communal undertones and would have affected riots as well as electoral politics. These two states are also different from the rest of our sample as they are not Hindu majority states - Punjab has a majority population of Sikhs and Jammu \& Kashmir has a majority population of Muslims. Hence we drop these two states and conduct the main regressions on a sample of 14 Hindu majority states. The results are presented in the first two columns of Table XI. We find that the coefficients in the first two specifications are unchanged but that in the last two they are considerably larger than in the full sample.

The demolition of the Babri Mosque in Ayodhya in 1992 was a major event in the history of independent India and the riots occurring in its aftermath in 1992 and in 1993 were widespread, and were covered widely in the national media and in academic writing soon after (Gopal 1993). To check that our results are not being driven mainly by this one major event, we drop the years 1993 and 1994 and run the regressions. The results are presented in columns 3 and 4 . We find that the coefficients are still positive but they lose statistical significance in the IV specifications. This may be because in 
non-Hindu majority states, the riots may be having different effects compared to Hindu majority states. To check this we run the regressions without Jammu and Kashmir, and Punjab (columns 5 and 6), and find that the coefficients are similar in magnitude and significance to earlier regressions.

We also drop the years after the two years in which there were the maximum number of riots, 1986 and 1990. We find that the coefficient estimates are positive and significant and slightly larger than the estimates for the full sample.

[Table XI here]

\subsubsection{Lagged dependent variable}

Another issue that may be important is the effect of the vote share of the BJP in the last election. This may affect both riots and the vote share in the next election. We argue that the effect of the previous election on riots would work through the government and we do control for having a BJP government in the state. We also find that even if we explicitly control for the BJP's vote share in the last election, the coefficient is not statistically significant, as shown in Table XII. This regression is susceptible to Nickell bias, but as the coefficient on lagged BJP vote share is not significant, and the variable is not included in our preferred specification, we do not attempt to correct for it here.

[Table XII here]

\subsubsection{Shorter intervals of time}

Thus far we have conducted the analysis at the level of the year. We do have data on the timing of the elections and the exact date of the riots, so it is possible to conduct the analysis using a shorter time interval. We construct the dataset at the monthly level. The month-wise distribution of elections, riots and the Festival instrument in Figure 4 shows why the calendar year is the most appropriate interval of time. We can see that elections are largely held in the months February, May and November with very few 
exceptions. The Festival instrument is also concentrated in the 7 months during which those festivals fall. Since some of these festivals are also region specific, a month-level analysis may implicitly give more weight to some regions over others. Doing the analysis at the monthly level does not work for two other reasons. One is that the instrument is very weak, but more importantly, it is possible that the timing of the election may not be exogenous. The election cycle is five-yearly, but there is a window of a few months around the time the five-year term of a legislative assembly ends, when the election can be held. So, it is possible that riots may lead to a change in the election dates. In any case, we conduct the analysis at the 3-month level to counteract the weak instrument problem to some extent. We exclude the month immediately preceding the election as we find that the Riot' variable calculated using the nearest riot in the three month period immediately preceding an election, is correlated with a reduction in the BJP's voteshare. Here the endogeneity of election timing may be at play. We look at four three-month periods viz, 2-4, 5-7, 8-10 and 11-13 months before the election. The results are presented in Table XIII. The coefficients are positive. Some of the coefficients are quite large compared to the original coefficient. This could be because of weak instrument bias as the regression where the instrument is strongest (5-7 months before the election), the coefficient is very close to the one obtained in the main regression.

[Figure 4 here]

[Table XIII here]

\subsubsection{Interactions between riots and demographic variables}

We check for the interaction of the Riot $_{i t-1}^{\prime}$ variable with demographic variables. The results are shown in Table XIV with two sets of regressions. In the first three columns we include the interaction of Riot $_{i t-1}^{\prime}$ with the percentage of Muslims, the literacy rate and the rate of urbanisation respectively. For the last three columns we create dummy variables for each demographic variable. For example, the 'high literacy rate dummy' 
takes a value 1 for the districts where the average literacy rate over 21 years is higher than the median. The interaction of either a demographic variable or a dummy with Riot $_{i t-1}^{\prime}$ is instrumented with the interaction of the same variable with Festival $_{i t-1}$. The regression results show that an increasing literacy rate is correlated with a reduced impact of riots on elections. We cannot interpret the coefficients on these interactions causally as these demographic variables may be correlated with other omitted district level variables which may be driving the effect. For instance, the strongly negative coefficients on the interactions with high average literacy and high urbanisation dummies could mean that the impact of riots on elections is lower in cities than in villages, but cities and villages differ on many parameters other than urbanisation and literacy.

\section{[Table XIV here]}

\subsubsection{Previous election}

We use the time period 1981-2001 because of availability of all data for this period and also because the BJP was recognised and contesting elections actively in this period. The BJP was formed in April 1980 as a faction of the erstwhile Janata party that lost the Lok Sabha elections earlier that year. In May 1980 Prime Minister Indira Gandhi dismissed a number of state governments and called premature elections. The BJP did contest in these elections but we did not include them in our sample as they were contesting the elections barely a month after forming the party and the elections were being held in extraordinary circumstances. In Table XV we present some regressions using this larger sample from 1980-2001. We construct the control variables for 1980 by extrapolating back from 1981 using the rate of change between 1981 and 1991 . We see that the coefficient estimate for our preferred specification is similar to that for the original sample but is not statistically significant. However, the coefficient estimates for two other specifications, one using All riots and the other using an interaction with literacy are strongly significant and very similar to those obtained using the original 
sample.

[Table XV here]

\subsubsection{Close elections}

We run our main specification on two sub-samples. Sub-sample 1 consists of all districts where in at least one electoral constituency the BJP won or lost by a margin of at most $3 \%$. Sub-sample 2 is similar with a smaller margin of $2 \%$. The idea is to investigate if the effect is very different when the election turns out to be close. The results are presented in Table XVI. The coefficients are not statistically significant, probably because of the small number of observations. We find that for Sub-sample 1 the point estimate is very similar to our original regression, while for Sub-sample 2 it is a little smaller.

[Table XVI here]

\subsubsection{Results for the Indian National Congress}

In all our regressions we have only examined until now the effect of riots on the vote share of the BJP. We can also investigate their effect on the other major national party, the Indian National Congress. Since these two parties compete against each other in most elections, we expect to see a negative effect on the vote share of the Congress and that is what we observe as shown in Table XVII. This is consistent with other studies from political science which have also suggested that the Congress's vote share in state assembly elections was affected adversely by the outbreak of an additional riot (Nellis, Weaver and Rosenzweig, 2015).

[Table XVII here]

All the robustness checks presented above confirm that the results observed in the main regressions are robust to different samples and specifications. We conclude there- 
fore that our results do represent the causal effect of religious riots on the vote share of the BJP in India.

\section{Conclusion}

Religious riots have complex underpinnings - frequently social, economic and political factors are involved. This paper demonstrates how these riots may influence voter behaviour and the incentives of political parties. Using data on Hindu-Muslims riots in India over 21 years, combined with electoral and demographic data, we demonstrate a causal link between electoral politics and communal riots. We use an innovative instrument that draws upon the random variation in the day of the week that important Hindu festivals fall on each year to isolate the causal effect of riots on electoral results. We find that riots occurring in the year preceding an election increase the vote share of the Hindu nationalist Bharatiya Janata Party in the election. Our results are robust to various robustness checks on the data and econometric analysis. This result does not imply that riots are not caused by electoral reasons. It may be the case that most of the riots are in fact the result of political calculations. Our attempt here is to disassociate those political reasons for riots and to examine the effect on electoral results of exogenously caused riots. The fact that our results show that a party systematically benefits from the riots, may establish that there is a clear incentive for this party to cause riots for electoral benefit. Therefore, our findings have important implications for the relationship between ethnic violence and electoral politics not just in India, but also in other diverse democratic societies. 


\section{Appendix 1}

\begin{tabular}{|c|c|c|c|c|c|}
\hline State & & & Festivals & & \\
\hline 1 Andhra Pradesh & Ramnavami & Durga ashtami & Navami & Dushehra & Diwali \\
\hline 2 Assam & Janmashtami & Durga ashtami & Navami & Dushehra & Diwali \\
\hline 3 Bihar & Holi & Ramnavami & Navami & Dushehra & Diwali \\
\hline 4 Gujarat & Holi & Ramnavami & Navami & Dushehra & Diwali \\
\hline 5 Haryana & Shivratri & Holi & Janmashtami & Dushehra & Diwali \\
\hline 6 Jammu and Kashmir & Shivratri & Ramnavami & Janmashtami & Dushehra & Diwali \\
\hline 7 Karnataka & Shivratri & Ganesh Chaturthi & Navami & Dushehra & Diwali \\
\hline 8 Kerala & Shivratri & Janmashtami & Navami & Dushehra & Diwali \\
\hline 9 Madhya Pradesh & Holi & Ramnavami & Janmashtami & Dushehra & Diwali \\
\hline 10 Maharashtra & Ramnavami & Ganesh Chaturthi & Navami & Dushehra & Diwali \\
\hline 11 Orissa & Holi & Durga ashtami & Navami & Dushehra & Diwali \\
\hline 12 Punjab & Holi & Ramnavami & Janmashtami & Dushehra & Diwali \\
\hline 13 Rajasthan & Holi & Ramnavami & Janmashtami & Dushehra & Diwali \\
\hline 14 Tamil Nadu & Janmashtami & Ganesh Chaturthi & Navami & Dushehra & Diwali \\
\hline 15 Uttar Pradesh & Ramnavami & Janmashtami & Navami & Dushehra & Diwali \\
\hline 16 West Bengal & Holi & Durga ashtami & Navami & Dushehra & Diwali \\
\hline
\end{tabular}

Table A.1 List of Hindu festivals by state used in the instrument Festival

\section{Appendix 2}

Let,

$y$ be the dependent variable, the BJP vote share

$x$ be the explanatory binary variable, Riot

$z$ be the instrument variable, Festival

Now, let $x$ be the result of under-reporting of the variable $x^{*}$ resulting from actual incidences of riots, with only a fraction $p$ of the actual riots getting reported.

Therefore, $E\left[x \mid x^{*}=1\right]=p, 0<p<1$, and $E\left[x \mid x^{*}=0\right]=0$ (using the first assumption)

Also, let the overall probability of at least one riot happening in a district $E\left[x^{*}\right]=$ $\lambda, 0<\lambda<1$. 
This implies that if a riot is reported, then the probability of an actual riot is 1, i.e.

$$
E\left[x^{*}=1 \mid x=1\right]=1
$$

But if no riot is reported, then the probability of an actual riot is

$$
E\left[x^{*}=1 \mid x=0\right]=E\left[x^{*}=1, x=0\right] / E[x=0]=\frac{\lambda(1-p)}{1-p \lambda}
$$

Using the third assumption, we know that the reporting or non-reporting of the riots is independent of our dependent variable.

$$
\therefore E\left[y \mid x, x^{*}\right]=E\left[y \mid x^{*}\right]
$$

Now, we want to look at how this biases our estimates.

The OLS estimate using only the reported riots would be,

$$
\begin{aligned}
\hat{\beta}_{O L S}= & E[y \mid x=1]-E[y \mid x=0] \\
= & E\left[y \mid x=1, x^{*}=1\right] E\left[x^{*}=1 \mid x=1\right]+E\left[y \mid x=1, x^{*}=0\right] E\left[x^{*}=0 \mid x=1\right] \\
& -E\left[y \mid x=0, x^{*}=1\right] E\left[x^{*}=1 \mid x=0\right]-E\left[y \mid x=0, x^{*}=0\right] E\left[x^{*}=0 \mid x=0\right]
\end{aligned}
$$

Rearranging and using (3)

$$
\begin{aligned}
\hat{\beta}_{O L S}= & E\left[y \mid x^{*}=1\right]\left(E\left[x^{*}=1 \mid x=1\right]-E\left[x^{*}=1 \mid x=0\right]\right) \\
& -E\left[y \mid x^{*}=0\right]\left(E\left[x^{*}=0 \mid x=0\right]-E\left[x^{*}=0 \mid x=1\right]\right)
\end{aligned}
$$

Using (1) and (2) 


$$
\begin{aligned}
\hat{\beta}_{O L S}= & E\left[y \mid x^{*}=1\right]\left(1-\frac{\lambda(1-p)}{1-p \lambda}\right) \\
& -E\left[y \mid x^{*}=0\right]\left(\frac{1-\lambda}{1-p \lambda}-0\right) \\
= & \frac{1-\lambda}{1-p \lambda}\left(E\left[y \mid x^{*}=1\right]-E\left[y \mid x^{*}=0\right]\right) \\
= & \frac{1-\lambda}{1-p \lambda} \hat{\beta}_{O L S}^{*}
\end{aligned}
$$

Since, $\frac{1-\lambda}{1-p \lambda}<1$, the OLS estimate will be biased towards zero.

Now, let us look at the IV estimate. The second assumption tells us that reporting is independent of Festival.

$$
\therefore E[x=1 \mid z]=p E\left[x^{*}=1 \mid z\right]
$$

The IV estimate calculated using the reported riots $x$ is given by

$$
\hat{\beta}_{I V}=\frac{E[y \mid z=1]-E[y \mid z=0]}{E[x \mid z=1]-E[x \mid z=0]}=\frac{1}{p} \frac{E[y \mid z=1]-E[y \mid z=0]}{E\left[x^{*} \mid z=1\right]-E\left[x^{*} \mid z=0\right]}=\frac{1}{p} \hat{\beta}_{I V}^{*}
$$

Since $0<p<1$, the magnitude of the IV estimate will be biased upwards. we have shown the proofs here using simple regressions but the principles apply to regressions with other covariates.

Now let us look at the probable magnitudes of the bias in our case. We know that the observed probability of riots as we see in the data of $p \lambda=0.07$ and the rate of reporting is approximately $p=0.77$. Hence, the actual probability of at least one riot happening in a district in a year $\lambda=0.091$

The OLS is biased by $1-\frac{1-\lambda}{1-p \lambda}=1-\frac{0.91}{0.93} \simeq 2.2 \%$

The IV is biased by $1 / p-1=1 / 0.77-1 \simeq 30 \%$

Hence, the bias in the IV estimate is very large, and this may explain the estimates that we obtain. This is because the effect of the reporting rate $p$ on the OLS estimate 
is moderated by the overall probability $\lambda$, whereas the IV estimate is directly impacted by $p$. The lower the reporting rate the higher the bias in both cases, but the magnitude of the bias in bounded above by $\lambda$ in the OLS case, whereas in the case of IV, it is unbounded. 


\section{References}

Aidt, T. S., \& Franck, R. (2015). Democratization under the Threat of Revolution: Evidence from the Great Reform Act of 1832. Econometrica, 83(2), 505-547.

Ansolabehere, S. (2008). Voters, Candidates, and Parties. In Wittman, D.A., \& Weingast, B.R., eds, The Oxford Handbook of Political Economy. Oxford University Press: New York.

Beck, E. M., \& Tolnay, S. E. (1990). The killing fields of the deep south: the market for cotton and the lynching of blacks, 1882-1930. American Sociological Review, 526539.

Berman, E., Downey, M and Felter, J. (2015). Expanding Governance as Development: Evidence on Child Nutrition in the Philippines. Paper presented at 'The Political Economy of Social Conflict' Conference, Department of Economics, Yale University, 16-17 October 2015.

Berrebi, C. and Klor, E. F. (2008). Are Voters Sensitive to Terrorism? Direct Evidence from the Israeli Electorate. American Political Science Review, 102(03), 279301.

Blakeslee, D. (2013). Propaganda and Ethno-Religious Politics in Developing Countries: Evidence from India. Mimeo, Columbia.

Blattman, C. (2009). From Violence to Voting: War and Political Participation in Uganda. American Political Science Review, 103(02), 231-247.

Bohlken, A. T., \& Sergenti, E. J. (2010). Economic Growth and Ethnic Violence: An Empirical Investigation of Hindu-Muslim Riots in India. Journal of Peace Research, 47(5), 589-600.

Brass, P. R. (1997). Theft of an Idol: Text and Context in the Representation of Collective Violence. Princeton University Press.

Brass, P. R. (2003). The Production of Hindu-Muslim Violence in Contemporary India. University of Washington Press.

Census of India, 1981, 1991, 2001. Government of India.

Dinecco, M \& Onorato, M. G. (2015), The Economic Legacy of Warfare: Evidence from Urban Europe. Paper presented at 'The Political Economy of Social Conflict' Conference, Department of Economics, Yale University, 16-17 October 2015.

Downs, A. (1957). An Economic Theory of Democracy. Harper and Row: New York.

DiPasquale, D., \& Glaeser, E. L. (1998). The Los Angeles Riot and the Economics of Urban Unrest. Journal of Urban Economics, 43(1), 52-78.

Eifert, B., Miguel, E., \& Posner, D. N. (2010). Political Competition and Ethnic 
Identification in Africa. American Journal of Political Science, 54(2), 494-510.

Election Commission of India (1976). Delimitation of Parliamentary and Assembly Constituencies Order, 1976. Election Commission, New Delhi.

Esteban, J., \& Ray, D. (2008). On the Salience of Ethnic Conflict. The American Economic Review, 2185-2202.

Fair, R. C. (1996). Econometrics and Presidential Elections. The Journal of Economic Perspectives, 89-102.

Fearon, J.D. (1999). Why Ethnic Politics and "Pork" Tend to go Together. Mimeo, Stanford University.

Fearon, J.D. (2008). Ethnic Mobilization and Ethnic Violence. In Wittman, D.A., \& Weingast, B.R., eds, The Oxford Handbook of Political Economy. Oxford University Press: New York

Field, E., Levinson, M., Pande, R., \& Visaria, S. (2008). Segregation, Rent Control, and Riots: The Economics of Religious Conflict in an Indian City. The American Economic Review, 505-510.

Gopal, S. (1993). Anatomy of a Confrontation: The Ramjanmabhoomi-Babri Masjid Issue. Penguin: Delhi.

Glaeser, E. L. (2005).The Political Economy of Hatred. Quarterly Journal of Economics, 120 (1), 45-86.

Guha, R. (2007). India After Gandhi: The History of the World's Largest Democracy. Harper Collins Publishers: New York.

Horowitz, D. L. (1985). Ethnic Groups in Conflict. Univ of California Press.

Indian Statutory Commission Report, 1930: 97-107

Iyer, S. (2016). The New Economics of Religion. Forthcoming in the Journal of Economic Literature.

Iyer, S. (2002). Demography and Religion in India. Delhi: Oxford University Press. Jaffrelot, C. (2010). Religion, Caste, and Politics in India. Primus Books.

Jha, S. (2014). "Unfinished Business": Historic Complementarities, Political Competition and Ethnic Violence in Gujarat, Journal of Economic Behavior and Organisation, Vol. 104, August, pp.18-36.

Kleibergen, F. \& Paap, R. (2006). Generalized Reduced Rank Tests Using the Singular Value Decomposition. Journal of Econometrics, Vol. 133, pp. 97-126.

Kramer, G. H. (1971). Short-term Fluctuations in US Voting Behavior, 1896-1964. American Political Science Review, 65(01), 131-143.

Marshall, A. (1920), Principles of Economics, Book V, Great Minds Series, Prometheus Books: New York, 1997.

Michalopoulas, S. \& Papaioannou, E. (2015) The Long-Run Effects of the Scramble 
for Africa. Paper presented at 'The Political Economy of Social Conflict' Conference, Department of Economics, Yale University, 16-17 October 2015.

Mitra, A., \& Ray, D. (2014). Implications of an Economic Theory of Conflict: Hindu-Muslim Violence in India, Journal of Political Economy, 122(4), 719-765.

Muralidharan, S. (2014). Modi, Mulayam, Muzaffarnagar. Economic \& Political Weekly, 49(7), 35.

Nellis, G., Weaver, M. and Rosenzweig, S (2015), Do Parties matter for Ethnic Violence? Evidence from India. Mimeograph, Department of Political Science, Yale University.

Pandey, G. (2001). Remembering Partition: Violence, Nationalism and History in India. Cambridge University Press.

Papke, L. E., \& Wooldridge, J. M. (2008). Panel Data Methods for Fractional Response Variables with an Application to test Pass Rates. Journal of Econometrics, 145(1), 121-133.

Pathania, V., \& Tandon, S. (2011). Divisive Politics and Violence: Evidence from the Success of the Bharatiya Janata Party in India. Working paper.

Posner, D. N. (2004). The Political Salience of Cultural Difference: Why Chewas and Tumbukas are Allies in Zambia and Adversaries in Malawi. American Political Science Review, 98(4), 529-545.

Rao, M., Mishra, I., Singh, P., \& Bajpai, V. (2014). Fact Finding Report: Independent inquiry into Muzaffarnagar "riots". Economic \& Political Weekly, 49(2).

Sen, A. (2006). "Identity and Violence: The Illusion of Destiny", Allen Lane, UK.

Skaperdas, S. (2015), Guns, Lawyers and Markets: Economic Consequences of Costly Conflict. Paper presented at 'The Political Economy of Social Conflict' Conference, Department of Economics, Yale University, 16-17 October 2015.

Stigler, G. J. (1973). General Economic Conditions and National Elections. The American Economic Review, 160-167.

Stock, J.H. \& Yogo, M. (2005). Testing for Weak Instruments in Linear IV Regression. In D.W.K. Andrews and J.H. Stock, eds. Identification and Inference for Econometric Models: Essays in Honor of Thomas Rothenberg. Cambridge University Press: Cambridge.

Varshney, A. (2002). Ethnic Conflict and Civic Life: Hindus and Muslims in India. New Haven: Yale University Press.

Varshney, A., \& Gubler, J. R. (2012). Does the State promote Communal Violence for Electoral Reasons?. India Review, 11(3), 191-199.

Varshney, A. \& Wilkinson, S.I. (2004) "Varshney Wilkinson Dataset on HinduMuslim Violence in India, Version 2" 
Wilkinson, S. I. (2004). Votes and Violence: Electoral Competition and Ethnic Riots in India. Cambridge University Press.

Wilkinson, S. I. (2009). Riots. Annual Review of Political Science, 12, 329-343.

Zussman, A. (2014). The Effect of Political Violence on Religiosity. Journal of Economic Behavior \& Organization, 104, 64-83. 


\section{Tables}

Table I. The reported number and duration of riots in 339 Indian districts between 1980-2000

\begin{tabular}{|c|c|c|c|}
\hline \multicolumn{4}{|c|}{$\begin{array}{l}\text { Total observations: } 7119 \\
\text { Observations with at least one riot: } 499\end{array}$} \\
\hline Number of riots & Obs. & Duration & Obs. \\
\hline 1 & 357 & 1 day & 271 \\
\hline $2-5$ & 130 & 2-5 days & 159 \\
\hline$>5$ & 12 & $>5$ days & 69 \\
\hline
\end{tabular}


Table II. Description of the main variables

\begin{tabular}{|c|c|c|c|c|}
\hline Name & Type & Definition & $\begin{array}{l}\text { Mean } \\
\text { (S.D.) }\end{array}$ & Observations \\
\hline BJP vote share ${ }_{i t}$ & Fraction & $\begin{array}{l}\text { The aggregate vote share of BJP } \\
\text { in election in district } i \text { in year } t \\
\text { across all those constituencies in } \\
\text { which BJP fielded a candidate. }\end{array}$ & $\begin{array}{c}0.25 \\
(0.16)\end{array}$ & 1345 \\
\hline $\operatorname{Riot}_{i t-1}$ & Binary & $\begin{array}{l}\text { Equals one if a riot occurred in } \\
\text { district } i \text { in year } t-1\end{array}$ & $\begin{array}{c}0.07 \\
(0.26)\end{array}$ & 7119 \\
\hline BJP government ${ }_{i t-1}$ & Binary & $\begin{array}{l}\text { Equals one if BJP is part of the } \\
\text { government of the state in year } \\
t-1\end{array}$ & $\begin{array}{c}0.13 \\
(0.33)\end{array}$ & 7119 \\
\hline $\begin{array}{l}\text { Muslim population } \\
\text { share }_{\text {it }}\end{array}$ & Percentage & $\begin{array}{l}\text { Percentage of the population } \\
\text { that is Muslim in district } i \text { in year } \\
t\end{array}$ & $\begin{array}{c}11.91 \\
(13.96)\end{array}$ & 7019 \\
\hline Urbanisation $_{\text {it }}$ & Percentage & $\begin{array}{l}\text { Percentage of the population } \\
\text { that lives in urban areas in } \\
\text { district } i \text { in year } t\end{array}$ & $\begin{array}{c}22.12 \\
(15.33)\end{array}$ & 7019 \\
\hline Literacy $_{i t}$ & Percentage & $\begin{array}{l}\text { Percentage of the population } \\
\text { that is literate in district } i \text { in year } \\
t\end{array}$ & $\begin{array}{c}42.26 \\
(19.95)\end{array}$ & 7019 \\
\hline Tap Water $_{\text {it }}$ & Percentage & $\begin{array}{l}\text { Percentage of households in } \\
\text { district } i \text { in year } t \text { that have } \\
\text { access to tap water }\end{array}$ & $\begin{array}{l}29.05 \\
(19.09)\end{array}$ & 7019 \\
\hline Electricity $_{\mathrm{it}}$ & Percentage & $\begin{array}{l}\text { Percentage of households in } \\
\text { district } i \text { in year } t \text { that have } \\
\text { access to electricity }\end{array}$ & $\begin{array}{c}40.74 \\
(24.19)\end{array}$ & 7019 \\
\hline Festival $_{i t-1}$ & Binary & $\begin{array}{l}\text { Equals } 1 \text { if an important Hindu } \\
\text { festival in district } i \text { falls on a } \\
\text { Friday in year } t-1\end{array}$ & $\begin{array}{c}0.53 \\
(0.50)\end{array}$ & 7436 \\
\hline
\end{tabular}


Table III. Regression on BJP voteshare ${ }_{i t}$ of Riot $_{i t-1}$ and other variables

\begin{tabular}{|c|c|c|c|c|c|c|c|c|}
\hline \multicolumn{9}{|c|}{ Dependent variable is BJP voteshare ${ }_{i t}$} \\
\hline & \multicolumn{2}{|l|}{1} & \multicolumn{2}{|l|}{2} & \multicolumn{2}{|l|}{3} & \multicolumn{2}{|l|}{4} \\
\hline & $\mathrm{FE}$ & & $\mathrm{FE}$ & & $\mathrm{FE}$ & & $\mathrm{FE}$ & \\
\hline \multirow[t]{2}{*}{ Riot $_{i t-1}$} & 0.035 & $* * *$ & 0.033 & $* * *$ & 0.033 & **** & 0.032 & *** \\
\hline & $(0.012)$ & & $(0.012)$ & & $(0.012)$ & & $(0.012)$ & \\
\hline \multirow[t]{2}{*}{ BJP government $_{i t-1}$} & -0.007 & & -0.002 & & -0.009 & & -0.005 & \\
\hline & $(0.006)$ & & $(0.006)$ & & $(0.006)$ & & $(0.006)$ & \\
\hline Muslim population & & & -0.008 & & & & -0.010 & * \\
\hline share $_{i t}$ & & & $(0.006)$ & & & & $(0.006)$ & \\
\hline \multirow[t]{2}{*}{ Urbanisation $_{i t}$} & & & 0.003 & & & & 0.002 & \\
\hline & & & $(0.002)$ & & & & $(0.002)$ & \\
\hline \multirow[t]{2}{*}{ Literacy $_{i t}$} & & & -0.008 & $* * *$ & & & -0.007 & *** \\
\hline & & & $(0.002)$ & & & & $(0.002)$ & \\
\hline Electricity $_{i t}$ & & & & & -0.004 & **** & -0.004 & **** \\
\hline & & & & & $(0.001)$ & & $(0.001)$ & \\
\hline Tap water $_{i t}$ & & & & & 0.005 & **** & 0.005 & *** \\
\hline & & & & & $(0.001)$ & & $(0.001)$ & \\
\hline State fixed effects & No & & No & & No & & No & \\
\hline District fixed effects & Yes & & Yes & & Yes & & Yes & \\
\hline Quadratic time trend & Yes & & Yes & & Yes & & Yes & \\
\hline Number of districts & 338 & & 338 & & 338 & & 338 & \\
\hline Number of observations & 1345 & & 1337 & & 1337 & & 1337 & \\
\hline
\end{tabular}

Standard errors are clustered at district level and are shown in parentheses

Significance levels: *** - $1 \%$. $^{* *}-5 \%, *-10 \%$ 
Table IV. First stage regression on Riot $_{i t-1}$ of instrument variable Festival $_{i t-1}$

\begin{tabular}{|c|c|c|c|c|c|c|c|c|}
\hline \multicolumn{9}{|c|}{ Dependent variable is Rlot $_{\mathrm{it}-1}$} \\
\hline & 1 & & 2 & & 3 & & 4 & \\
\hline & $\mathrm{FE}$ & & $\mathrm{FE}$ & & $\mathrm{FE}$ & & $\mathrm{FE}$ & \\
\hline \multirow[t]{2}{*}{ Festival $_{i t-1}$} & 0.027 & $* * *$ & 0.029 & $* * *$ & 0.028 & $* * *$ & 0.029 & $* * *$ \\
\hline & $(0.005)$ & & $(0.005)$ & & $(0.005)$ & & $(0.005)$ & \\
\hline \multirow[t]{2}{*}{ BJP government $t_{i t-1}$} & -0.004 & & -0.002 & & -0.002 & & -0.002 & \\
\hline & $(0.010)$ & & $(0.010)$ & & $(0.010)$ & & $(0.010)$ & \\
\hline Demographic controls & No & & Yes & & No & & Yes & \\
\hline Public goods controls & No & & No & & Yes & & Yes & \\
\hline District fixed effects & Yes & & Yes & & Yes & & Yes & \\
\hline Quadratic time trend & Yes & & Yes & & Yes & & Yes & \\
\hline F-Stat & 26.1 & & 28.42 & & 26.85 & & 28.83 & \\
\hline Number of districts & 339 & & 339 & & 339 & & 339 & \\
\hline Number of observations & 7119 & & 7019 & & 7019 & & 7019 & \\
\hline
\end{tabular}

Standard errors are clustered at district level and are shown in parentheses

Significance levels: $* * *-1 \%{ }^{* *}-5 \%, *-10 \%$ 
Table V. Reduced form and IV regressions using Festival $_{i t-1}$ as an instrument variable for

$$
\text { Riot }_{i t-1}
$$

\begin{tabular}{|c|c|c|c|c|c|c|c|c|}
\hline \multicolumn{9}{|c|}{ Dependent variable is BJP vote share ${ }_{i t}$} \\
\hline & 1 & & 2 & & 3 & & 4 & \\
\hline & $\mathrm{FE}$ & & $\mathrm{FE}$ & & $\mathrm{FE}$ & & $\mathrm{FE}$ & \\
\hline Festival $_{i t-1}$ & $\begin{array}{c}0.029 \\
(0.009)\end{array}$ & $* * *$ & $\begin{array}{c}0.021 \\
(0.009)\end{array}$ & ** & $\begin{array}{c}0.025 \\
(0.009)\end{array}$ & $* * *$ & $\begin{array}{c}0.018 \\
(0.009)\end{array}$ & * \\
\hline BJP government $_{i t-1}$ & $\begin{array}{l}-0.013 \\
(0.007)\end{array}$ & & $\begin{array}{l}-0.007 \\
(0.007)\end{array}$ & & $\begin{array}{l}-0.014 \\
(0.007)\end{array}$ & ** & $\begin{array}{l}-0.009 \\
(0.007)\end{array}$ & \\
\hline Demographic controls & No & & Yes & & No & & No & \\
\hline Public goods controls & No & & No & & Yes & & No & \\
\hline District fixed effects & Yes & & Yes & & Yes & & Yes & \\
\hline Quadratic time trend & Yes & & Yes & & Yes & & Yes & \\
\hline Number of districts & 338 & & 338 & & 338 & & 338 & \\
\hline Number of observations & 1345 & & 1337 & & 1337 & & 1337 & \\
\hline & 5 & & 6 & & 7 & & 8 & \\
\hline & IV FE & & IV FE & & IV FE & & IV FE & \\
\hline Riot $_{i t-1}$ & $\begin{array}{c}0.402 \\
(0.150)\end{array}$ & $* * *$ & $\begin{array}{c}0.269 \\
(0.134)\end{array}$ & $* *$ & $\begin{array}{c}0.350 \\
(0.142)\end{array}$ & $* *$ & $\begin{array}{c}0.234 \\
(0.128)\end{array}$ & * \\
\hline BJP government $t_{i t-1}$ & $\begin{array}{l}-0.007 \\
(0.010)\end{array}$ & * & $\begin{array}{l}-0.002 \\
(0.008)\end{array}$ & & $\begin{array}{l}-0.009 \\
(0.009)\end{array}$ & & $\begin{array}{l}-0.005 \\
(0.007)\end{array}$ & \\
\hline Demographic controls & No & & Yes & & No & & Yes & \\
\hline Public goods controls & No & & No & & Yes & & Yes & \\
\hline District fixed effects & Yes & & Yes & & Yes & & Yes & \\
\hline Quadratic time trend & Yes & & Yes & & Yes & & Yes & \\
\hline Kleibergen-Paap F stat & 19.37 & & 18.71 & & 18.78 & & 19.41 & \\
\hline Number of districts & 334 & & 334 & & 334 & & 334 & \\
\hline Number of observations & 1341 & & 1333 & & 1333 & & 1333 & \\
\hline
\end{tabular}

Standard errors are clustered at district level and are shown in parentheses

Significance levels: *** - $1 \%$. $^{* *}-5 \%, *-10 \%$ 
Table VI. Regression results for different standard deviations for $\phi($.

\begin{tabular}{|ccccccc|}
\hline $\begin{array}{l}\text { Standard deviation } \\
\text { in km }\end{array}$ & $\begin{array}{c}\text { Coefficient } \\
\text { estimate }\end{array}$ & SE & $\begin{array}{c}\text { First stage KP } \\
\text { F-stat }\end{array}$ & $\begin{array}{c}\text { Root mean } \\
\text { squared } \\
\text { error }\end{array}$ & $\begin{array}{c}\text { Akaike's } \\
\text { Information } \\
\text { Criterion }\end{array}$ & $\begin{array}{c}\text { Bayesian } \\
\text { Information } \\
\text { Criterion }\end{array}$ \\
\hline 100 & $0.072^{* *}$ & 0.037 & 123.8 & 0.0988 & -2754.0 & -2707.2 \\
150 & $0.065^{* *}$ & 0.033 & 154.4 & 0.0984 & -2764.4 & -2717.6 \\
200 & $\mathbf{0 . 0 6 6 * *}$ & $\mathbf{0 . 0 3 3}$ & 164.7 & $\mathbf{0 . 0 9 8 4}$ & $\mathbf{- 2 7 6 4 . 7}$ & $\mathbf{- 2 7 1 8 . 0}$ \\
250 & $0.071^{* *}$ & 0.036 & 161.8 & 0.0986 & -2760.6 & -2713.8 \\
300 & $0.078^{* *}$ & 0.04 & 153.6 & 0.0988 & -2755.0 & -2708.2 \\
\hline
\end{tabular}

Standard errors are clustered at district level Significance levels: ***-1\%,**-5\%,* - $10 \%$ 
Table VII. Regressions using the Papke-Wooldridge method

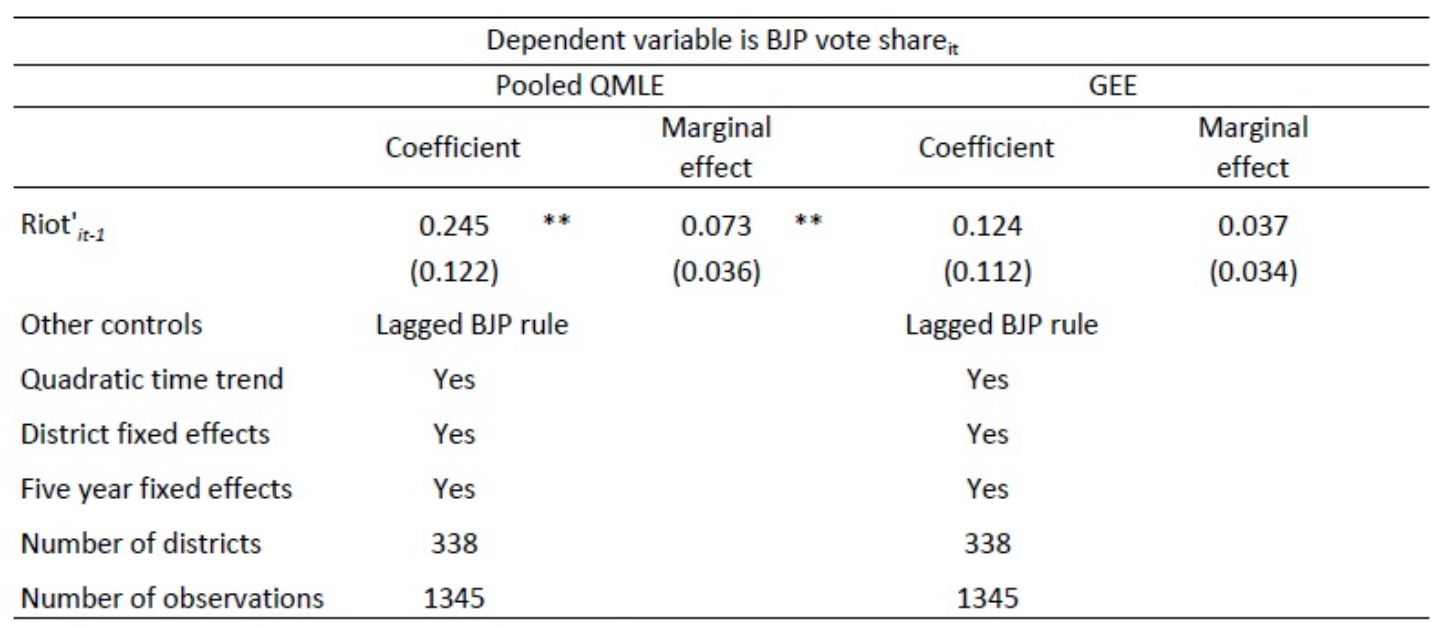

Standard errors are clustered at the district level, and are shown in parentheses Significance levels: *** $-1 \%{ }^{* *}-5 \%, *-10 \%$ 
Table VIII. Regressions using riots in a 12-month period before the election as an explanatory variable

\begin{tabular}{|c|c|c|c|c|}
\hline \multicolumn{5}{|c|}{ Dependent variable is BJP vote share $_{i t}$} \\
\hline & 1 & & 2 & \\
\hline & $\mathrm{FE}$ & & IV FE & \\
\hline $\operatorname{Riot}_{i t-12 m o n t h s}$ & 0.063 & $* * *$ & 0.070 & ** \\
\hline & $(0.010)$ & & $(0.035)$ & \\
\hline Other controls & Yes & & Yes & \\
\hline Quadratic time trend & Yes & & Yes & \\
\hline District fixed effects & Yes & & Yes & \\
\hline KP Wald F stat & & & 114.5 & \\
\hline Number of districts & 338 & & 334 & \\
\hline Number of observatior & 1337 & & 1333 & \\
\hline
\end{tabular}

Standard errors are clustered at the district level, and are shown in parentheses Significance levels: *** $-1 \%{ }^{* *}-5 \%, *-10 \%$ 
Table IX. Regressions using Festival 1 and Festival 2 as instruments

\begin{tabular}{|c|c|c|c|c|}
\hline \multicolumn{5}{|c|}{ Dependent variable is BJP voteshare $_{\text {it }}$} \\
\hline & Festival 1 & & Festival 2 & \\
\hline & IV FE & & IV FE & \\
\hline \multirow{2}{*}{$\operatorname{Riot}_{i t-1}^{\prime}$} & 0.142 & $* * *$ & 0.061 & $*$ \\
\hline & $(0.022)$ & & $(0.036)$ & \\
\hline Other controls & Yes & & Yes & \\
\hline District fixed effects & Yes & & Yes & \\
\hline Quadratic time trend & Yes & & Yes & \\
\hline Kleibergen-Paap F stat & 227.1 & & 174.6 & \\
\hline Number of districts & 334 & & 334 & \\
\hline Number of observations & 1333 & & 1333 & \\
\hline
\end{tabular}

Standard errors are clustered at district level and are shown in parentheses Significance levels: *** $-1 \%{ }^{* *}-5 \%, *-10 \%$ 
Table X. Regressions with time fixed effects and region specific time trends

\begin{tabular}{|c|c|c|c|c|c|c|c|}
\hline \multicolumn{8}{|c|}{ Dependent variable is BJP vote share ${ }_{i t}$} \\
\hline & 1 & 2 & 3 & 4 & 5 & 6 & 7 \\
\hline & $\mathrm{FE}$ & $\mathrm{FE}$ & IV FE & IV FE & IV FE & IV FE & IV FE \\
\hline \multirow{2}{*}{$\operatorname{Riot}_{i t-1}^{\prime}$} & -0.005 & $0.048^{* * *}$ & 0.039 & 0.048 & & & \\
\hline & $(0.013)$ & $(0.011)$ & $(0.117)$ & $(0.033)$ & & & \\
\hline \multirow[t]{2}{*}{ All riots $s_{i t-1}$} & & & & & $0.024^{* * *}$ & $0.012^{* * *}$ & $0.021^{* * *}$ \\
\hline & & & & & $(0.006)$ & $(0.002)$ & $(0.006)$ \\
\hline Year fixed effects & Yes & No & Yes & No & Yes & No & Yes \\
\hline Region specific linear trends & No & Yes & No & Yes & No & Yes & Yes \\
\hline Other controls & Yes & Yes & Yes & Yes & Yes & Yes & Yes \\
\hline Quadratic time trend & No & Yes & No & Yes & No & Yes & No \\
\hline District fixed effects & Yes & Yes & Yes & Yes & Yes & Yes & Yes \\
\hline K-P Wald F stat & & & 8.1 & 170.0 & 50.2 & 573.0 & 54.6 \\
\hline Number of districts & 338 & 338 & 334 & 334 & 334 & 334 & 334 \\
\hline Number of observations & 1337 & 1337 & 1333 & 1333 & 1333 & 1333 & 1333 \\
\hline
\end{tabular}

Standard errors are clustered at the district level, and are shown in parentheses Significance levels: ${ }^{* * *}-1 \%{ }^{* *}-5 \%, *-10 \%$ 
Table XI. Regressions without observations from certain years, Jammu and Kashmir, and

Punjab

\begin{tabular}{lccccccccc}
\hline \multicolumn{8}{c}{ Dependent variable is BJP voteshare } \\
\hline
\end{tabular}

Standard errors are clustered at district level and are shown in parentheses

Significance levels: ${ }^{* * *}-1 \%{ }^{* *}-5 \%, *-10 \%$ 
Table XII. Regressions with lagged vote share

\begin{tabular}{lcc}
\hline \multicolumn{3}{c}{ Dependent variable is BJP vote share $_{\text {it }}$} \\
\hline & 1 & 2 \\
\hline Riot' $^{\prime}{ }_{\text {tt-1 }}$ & $\mathrm{FE}$ & IV FE \\
& $0.066 \quad * * *$ & $0.077 \quad * * *$ \\
& $(0.011)$ & $(0.028)$ \\
BJP vote share & -0.013 & -0.009 \\
in last election & $(0.043)$ & $(0.045)$ \\
Other controls & Yes & Yes \\
Quadratic time trend & Yes & Yes \\
District fixed effects & Yes & Yes \\
K-P Wald F stat & & 180.2 \\
Number of districts & 326 & 314 \\
Number of observations & 1203 & 1191 \\
\hline
\end{tabular}

Standard errors are clustered at the district level, and are given in parentheses Significance levels: ${ }^{* * *}-1 \%{ }^{* *}-5 \%, *-10 \%$ 
Table XIII. Regressions conducted at different monthly levels

\begin{tabular}{|c|c|c|c|c|}
\hline \multicolumn{5}{|c|}{ Dependent variable is BJP vote share ${ }_{\text {it }}$} \\
\hline & 1 & 2 & 3 & 4 \\
\hline & IV FE & IV FE & IV FE & IV FE \\
\hline Riot'; $_{i}$ between two to & 0.287 & & & \\
\hline four months before the election & $(0.186)$ & & & \\
\hline Riot $_{i}$, between five to & & 0.068 & & \\
\hline seven months before the election & & $(0.030)$ & & \\
\hline Riot' $_{i}$ between eight to & & & 0.392 & $* * *$ \\
\hline ten months before the election & & & $(0.107)$ & \\
\hline Riot' $_{i}$ between eleven to & & & & 0.427 \\
\hline thirteen months before the election & & & & $(0.222)$ \\
\hline Other controls & Yes & Yes & Yes & Yes \\
\hline Quadratic time trend & Yes & Yes & Yes & Yes \\
\hline District fixed effects & Yes & Yes & Yes & Yes \\
\hline Quarter fixed effects & Yes & Yes & Yes & Yes \\
\hline K-P Wald F stat & 2.9 & 257.5 & 23.9 & 7.3 \\
\hline Number of districts & 334 & 334 & 334 & 334 \\
\hline Number of observations & 1333 & 1333 & 1333 & 1333 \\
\hline
\end{tabular}

Standard errors are clustered at the district level, and are given in parentheses

Significance levels: *** - $1 \%{ }^{* *}-5 \%, *-10 \%$ 
Table XIV. Regressions of interactions with demographic characteristics

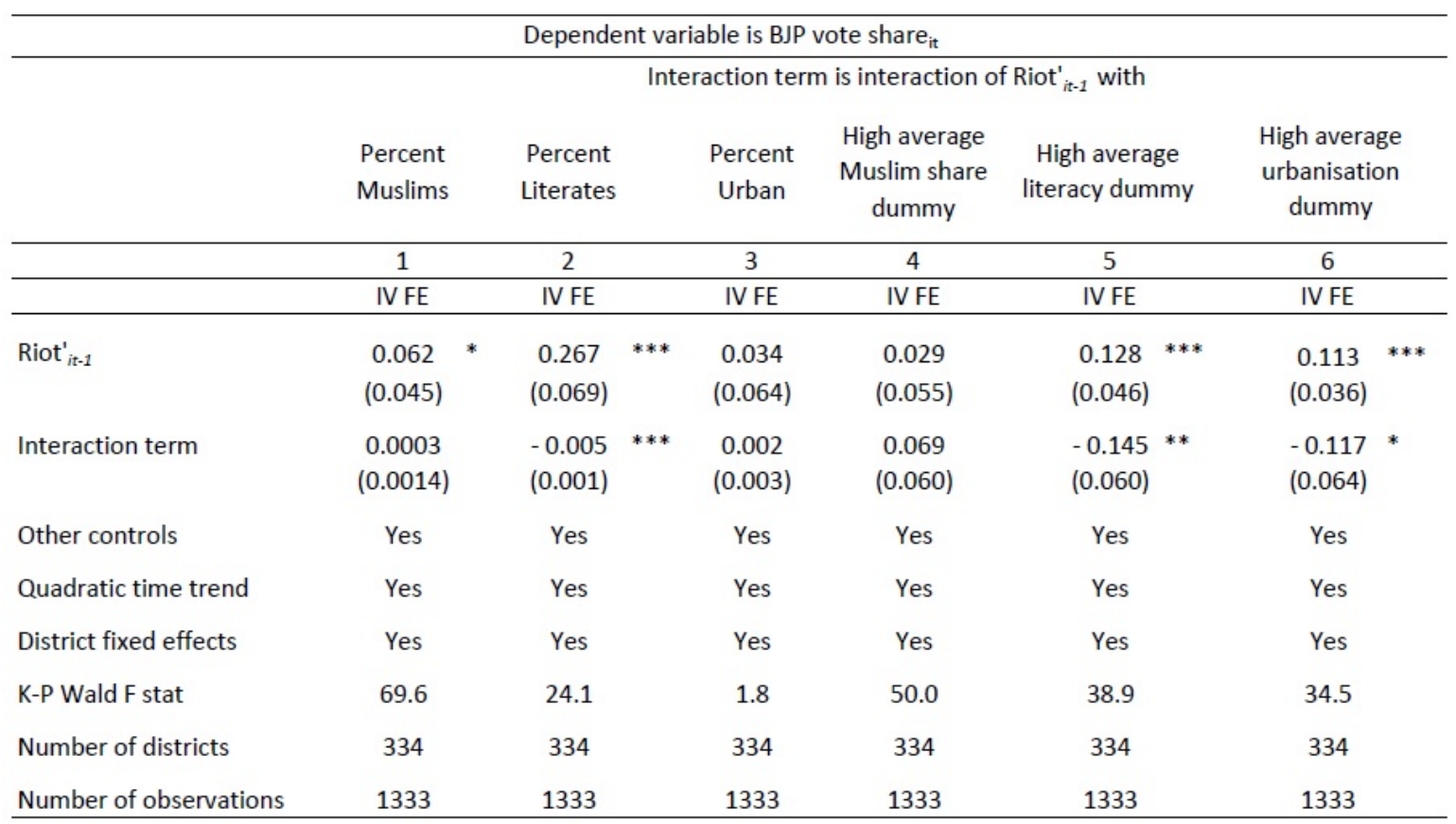

Standard errors are clustered at the district level, and are given in parentheses Significance levels: *** $-1 \%{ }^{* *}-5 \%, *-10 \%$ 
Table XV. Regressions including state elections held in 1980

\begin{tabular}{|c|c|c|c|c|c|}
\hline \multicolumn{6}{|c|}{ Dependent variable is BJP vote share $\mathrm{it}_{\mathrm{it}}$} \\
\hline & 1 & 2 & & 3 & \\
\hline & IV FE & IV FE & & IV FE & \\
\hline \multirow[t]{2}{*}{$\operatorname{Riot}_{i t-1}^{\prime}$} & 0.060 & & & 0.232 & $* * *$ \\
\hline & $(0.041)$ & & & $(0.068)$ & \\
\hline All riots ${ }_{i t-1}$ & & 0.024 & $* * *$ & & \\
\hline & & $(0.006)$ & & & \\
\hline \multirow[t]{2}{*}{ Riot $_{i t-1}^{\prime} \times$ Literacy rate $_{i t}$} & & & & -0.004 & $* * *$ \\
\hline & & & & $(0.001)$ & \\
\hline Other controls & Yes & Yes & & Yes & \\
\hline Quadratic time trend & Yes & No & & Yes & \\
\hline District fixed effects & Yes & Yes & & Yes & \\
\hline $\begin{array}{l}\text { Year fixed effects and } \\
\text { region specific linear trends }\end{array}$ & No & Yes & & No & \\
\hline K-P Wald F stat & 91.1 & 57.13 & & 8.1 & \\
\hline Number of districts & 335 & 335 & & 334 & \\
\hline Number of observations & 1563 & 1563 & & 1333 & \\
\hline
\end{tabular}

Standard errors are clustered at the district level, and are shown in parentheses Significance levels: ${ }^{* * *}-1 \%{ }^{* *}-5 \%, *-10 \%$ 
Table XVI. Regressions using close election sub-samples

\begin{tabular}{lcc}
\hline \multicolumn{3}{c}{ Dependent variable is BJP vote share $_{\text {it }}$} \\
\hline & Subsample 1 & Subsample 2 \\
\hline Riot' $^{\prime}{ }_{\text {It- } 1}$ & 0.064 & IV FE \\
& $(0.044)$ & 0.044 \\
Other controls & Yes & $(0.048)$ \\
Quadratic time trend & Yes & Yes \\
District fixed effects & Yes & Yes \\
K-P Wald F stat & 38.8 & Yes \\
Number of districts & 151 & 39.4 \\
Number of observations & 399 & 120 \\
\hline
\end{tabular}

Standard errors are clustered at the district level, and are given in parentheses Significance levels: ${ }^{* * *}-1 \%{ }^{* *}-5 \%, *-10 \%$ 
Table XVII. Regressions for the Indian National Congress

\begin{tabular}{lcc}
\hline \multicolumn{3}{c}{ Dependent variable is INC vote share $_{\text {it }}$} \\
\hline \multicolumn{1}{c}{1} & 2 \\
\hline Riot $_{\text {it-1 }}$ & $0.018 * *$ & FE FE \\
& $(0.009)$ & $(0.030)$ \\
INC government & it-1 & $-0.018 * * *$ \\
& $(0.005)$ & -0.022 \\
Other controls & Yes & $(0.006)$ \\
Quadratic time trend & Yes & Yes \\
District fixed effects & Yes & Yes \\
K-P Wald F stat & & Yes \\
Number of districts & 338 & 169.7 \\
Number of observations & 1401 & 338 \\
\hline
\end{tabular}

Standard errors are clustered at the district level, and are shown in parentheses Significance levels: $* * *-1 \%{ }^{* *}-5 \%, *-10 \%$ 
Figures

Figure 1. Number of riots by year in all 339 districts

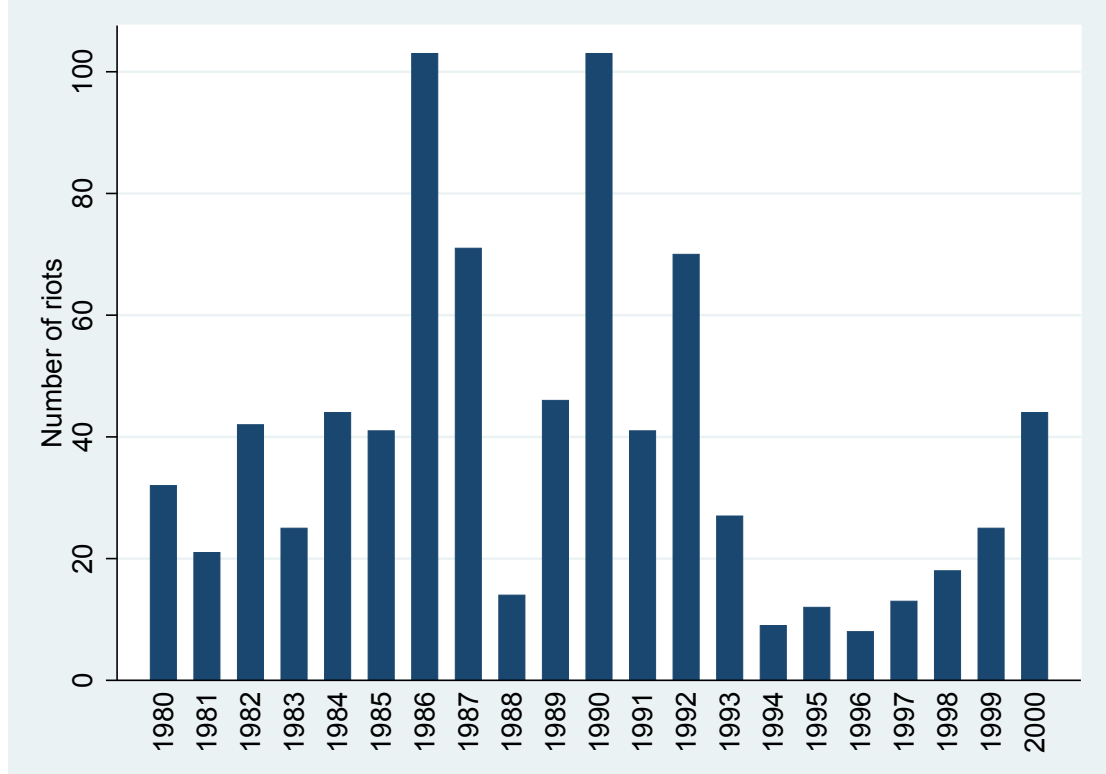


Figure 2. Change in the effect of riots on turnout with respect to percentage of Muslims

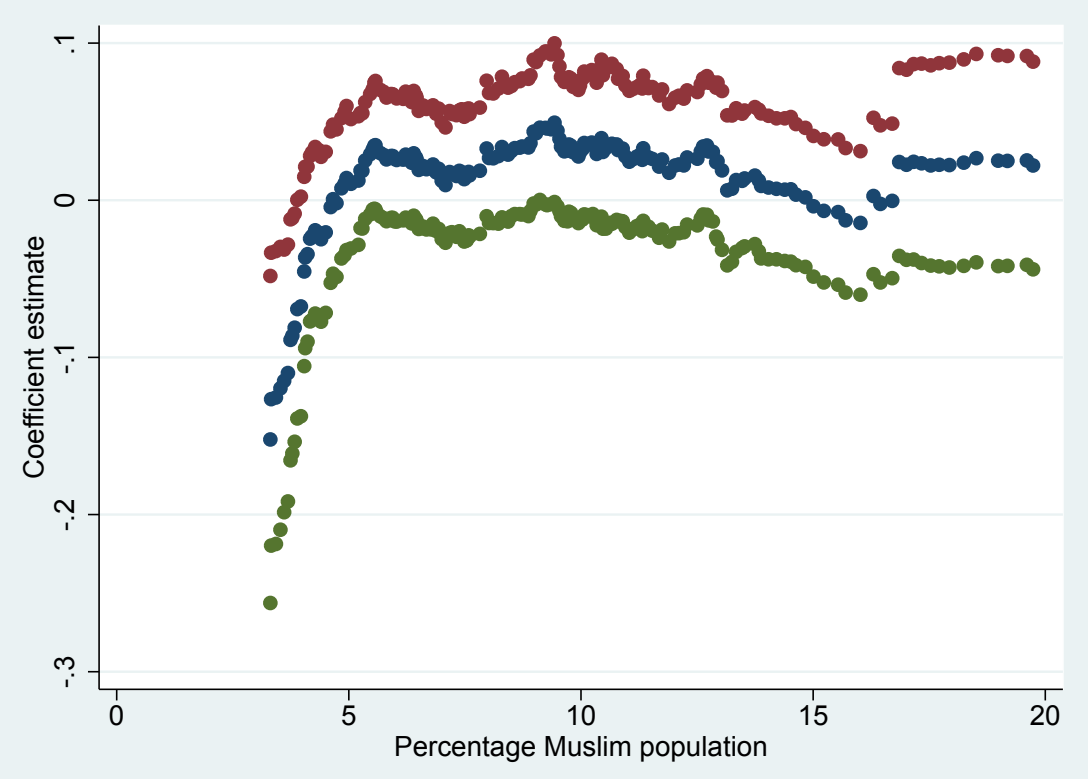


Figure 3. Coefficients on different lags
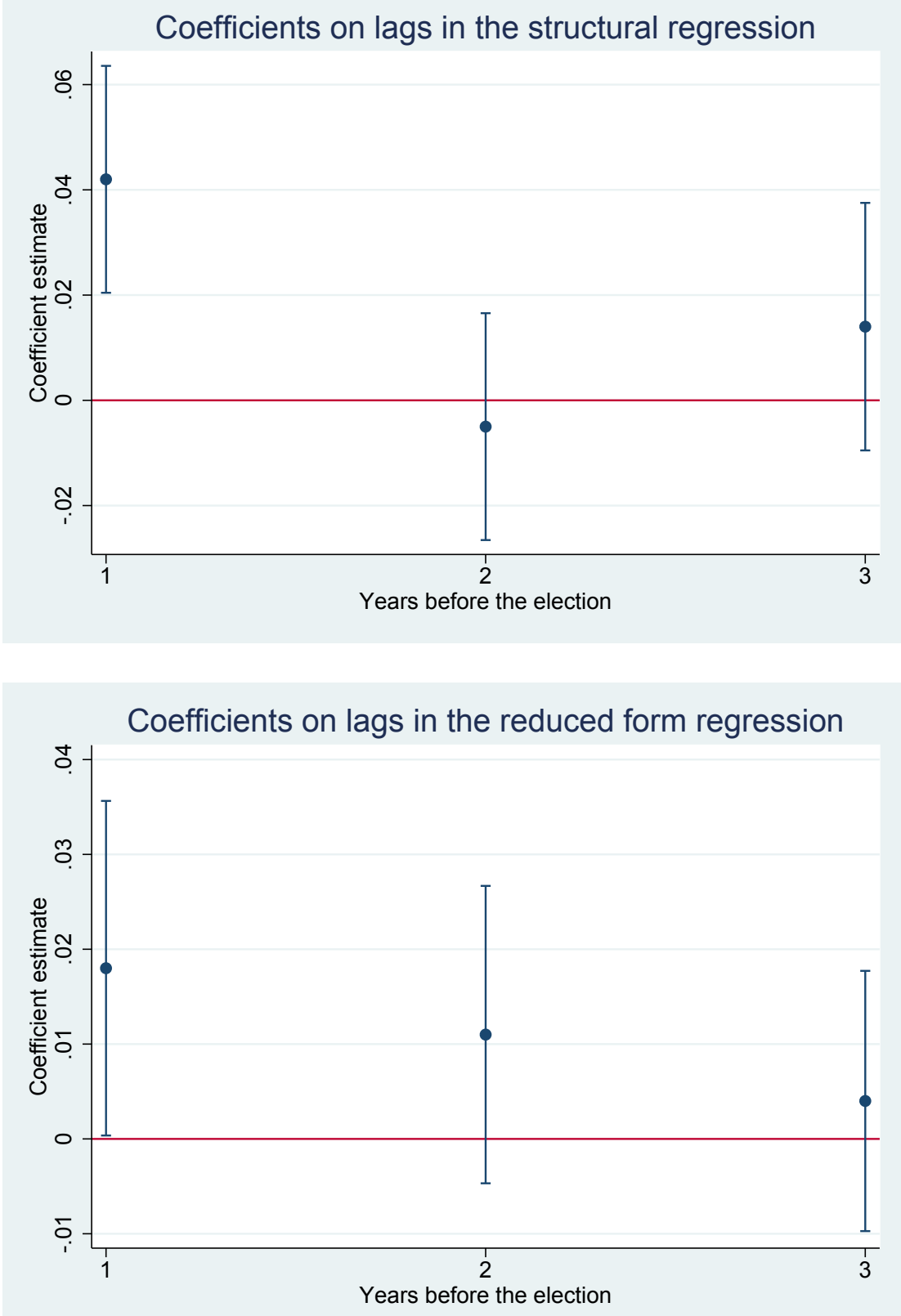
Figure 4. Distribution of elections, the festival instrument and number of riots over calendar months

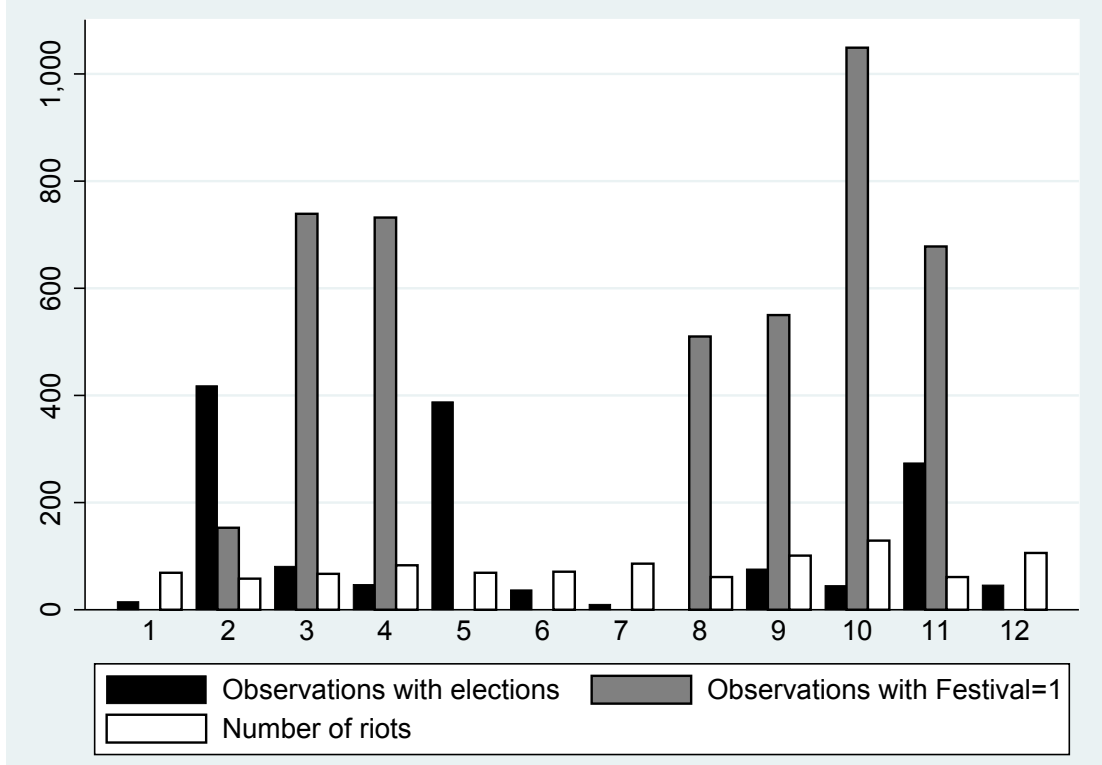

